\title{
Effects of co-formulants on the absorption and secretion of active substances in plant protection products in vitro
}

\author{
Mawien Karaca ${ }^{1,2} \cdot$ Benjamin Christian Fischer ${ }^{1} \cdot$ Christian Tobias Willenbockel $^{1} \cdot$ Tewes Tralau $^{1}$. \\ Philip Marx-Stoelting ${ }^{1,2}$ (D) Denise Bloch ${ }^{1}$
}

Received: 16 April 2021 / Accepted: 12 August 2021 / Published online: 20 August 2021

(c) The Author(s) 2021

\begin{abstract}
Currently, the authorisation process for plant protection products (PPPs) relies on the testing of acute and topological toxicity only. Contrastingly, the evaluation of active substances includes a more comprehensive set of toxicity studies. Nevertheless, mixture effects of active ingredients and co-formulants may result in increased toxicity. Therefore, we investigated effects of surface active co-formulants on the toxicity of two PPPs focussing on qualitative and quantitative toxicokinetic effects on absorption and secretion. The respective products are based on the active substances abamectin and fluroxypyr-meptyl and were tested for cytotoxicity in the presence or absence of the corresponding surfactants and co-formulants using Caco-2 cells. In addition, the effect of co-formulants on increased cellular permeation was quantified using LC-MS/MS, while potential kinetic mixture effects were addressed by fluorescence anisotropy measurements and ATPase assays. The results show that surface active co-formulants significantly increase the cytotoxicity of the investigated PPPs, leading to more than additive mixture effects. Moreover, analytical investigations show higher efflux ratios of both active substances and the metabolite fluroxypyr upon combination with certain concentrations of the surfactants. The results further point to a significant and concentration-dependent inhibition of Pgp transporters by most of the surfactants as well as to increased membrane fluidity. Altogether, these findings strongly support the hypothesis that surfactants contribute to increased cytotoxicity of PPPs and do so by increasing the bioavailability of the respective active substances.
\end{abstract}

Keywords Mixture effects $\cdot$ Co-formulants $\cdot$ Surfactants $\cdot$ Toxicokinetic $\cdot$ Plant protection products $\cdot$ Pesticides

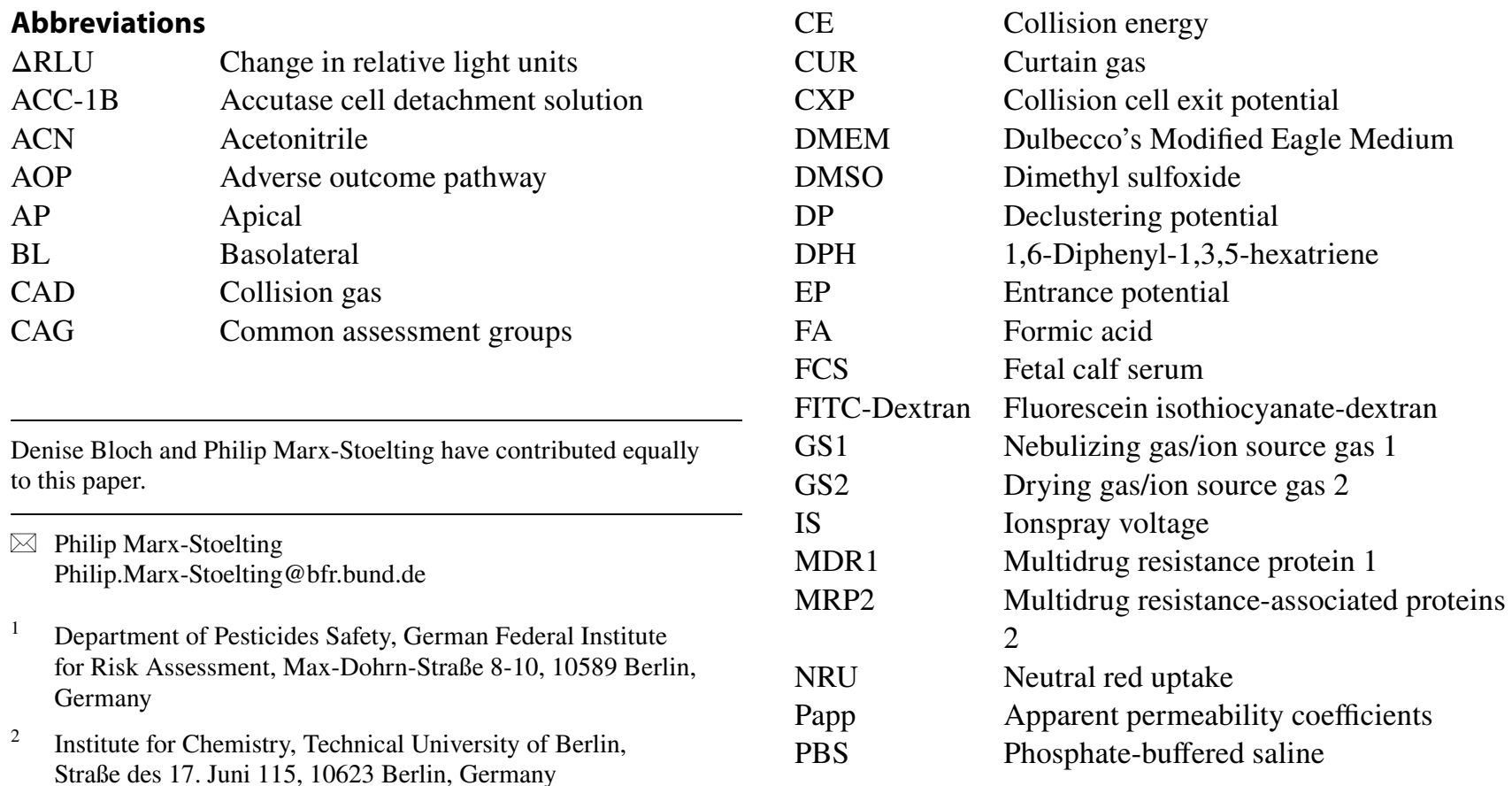




$\begin{array}{ll}\text { Pgp } & \text { P-glycoproteins } \\ \text { POE } & \text { Polyoxyethylene } \\ \text { PPP } & \text { Plant protection products } \\ \text { QuEChERS } & \begin{array}{l}\text { Quick, Easy, Cheap, Effective, Rugged } \\ \text { and Safe }\end{array} \\ & \text { Water soluble tetrazolium } \\ \text { WST-1 } & \text { Relative potency factor } \\ \text { RPF } & \text { Anisotropy value } \\ r \text { value } & \text { Standard deviation } \\ \text { SD } & \text { Transepithelial electrical resistance } \\ \text { TEER } & \text { Temperature of ion source } \\ \text { TEM } & \text { Tetrahydrofuran } \\ \text { THF } & \end{array}$

\section{Introduction}

Plant protection products (PPPs) are mixtures that, apart from the active substances, also contain a wide variety of co-formulants. Co-formulants provide PPPs with required properties for their application, thereby supporting the efficacy of active substances (Hazen 2000). In the context of PPP toxicity, it is usually the active substances that are assumed to be the main drivers of toxicity. Consequently, Regulation (EU) 283/2013 requires comprehensive mammalian toxicity testing for acute, chronic and sub-chronic effects only for the active substance but not for PPPs (EC 2013a). The latter are mainly evaluated for acute effects with their admission requiring tests for acute toxicity, irritation and skin sensitisation (EC 2013b). The co-formulants used therein do not require any further particular toxicological evaluation or authorisation as part of PPP Regulation (EU) 1107/2009 (EC 2009). Instead they are commonly subject to the REACH regulation and hence toxicologically tested and assessed depending on their annual production volume.

Although co-formulants are by definition non-active, they contribute to toxicodynamic or toxicokinetic mixture effects, potentially resulting in the altered toxicity of the PPP. In recent years several articles were published comparing active substances and PPPs, showing that the products may exhibit increased toxic effects (Adler-Flindt and Martin 2019; Hernandez et al. 2013; Zahn et al. 2018). Furthermore, Regulation (EU) 1107/2009 requires that "interaction between the active substance, safeners, synergists and coformulants shall be taken into account" in the evaluation and authorisation of PPPs (EC 2009).

Yet, PPP risk assessment traditionally focuses on active substance(s) without particularly assessing specific effects of co-formulants (EC 2009). Instead, PPP hazard assessment is often based on the CLP calculation method, which relies on information on single substances and the additivity principle (EC 2008). Assuming a similar mode of action for the ingredients, this approach is viewed as a worstcase estimation of mixture effects (Backhaus et al. 2004;
Junghans et al. 2006). It should be noted, however, that this assumption only applies to the toxicodynamic properties, and less so to potential toxicokinetic interactions (Van Cott et al. 2018). This in turn can lead to a potential underestimation of mixture effects as also indicated by previous studies (Van Cott et al. 2018). Also, Kurth et al. (2019) observed discrepancies between the hazard of PPPs classified in vivo and the results of the calculation method for acute oral and inhalation toxicity.

Therefore, there is a need for a more systematic approach to better understand the influence of co-formulants on the active substance's toxicokinetics. Synergistic effects through toxicokinetic interactions may occur, for example by co-formulants significantly increasing the uptake or absorption of the active ingredient or other components leading to higher bioactivity or bioavailability (Kienzler et al. 2014).

Several chemicals with surface active properties may enhance the oral bioavailability of active substances/drugs as described previously (Weinheimer et al. 2017). The absorption enhancement can be due to increased membrane fluidity resulting in an increased passive transport flux (Woodcock et al. 1992) and/or due to the inhibition of active transporters (Li-Blatter et al. 2009). Furthermore, an interference with the tight junctions, especially for anionic surfactants, has been described (Aungst 1999).

Several surfactants, especially those with non-ionic properties, have been described to inhibit transporters in the gastrointestinal tract, i.e. tweens, cremophors and pluronic block copolymers (Nerurkar et al. 1996; Rege et al. 2001; Woodcock et al. 1992). Mostly the P-glycoproteins (Pgp), also known as multidrug resistance protein 1 (MDR1) or $\mathrm{ABCB} 1$, are effectively inhibited by these substances. Their further ability to alter membrane fluidity and thereby forcing a conformational change of Pgp is assumed to lead to the inhibition of Pgp's ATPase activity (Dudeja et al. 1995; Woodcock et al. 1992). It has also been reported that Pgp inhibition may be induced by the polyoxyethylene (POE) structure of these surfactants, caused by changes in membrane fluidity (Hugger et al. 2002).

In the present paper, we focused on the impact of co-formulants with surface active properties on the absorption of active substances in PPPs. Our main interest was the investigation of effects as they may occur when handling PPPs. Two PPPs containing surface active co-formulants, used as emulsifiers, dispersing or wetting agents, were selected for further investigation: an insecticide containing abamectin and an herbicide containing fluroxypyr-meptyl.

The aim of this work was to investigate toxicokinetic mixture effects of surface active co-formulants and active substances on absorption and secretion in vitro. Transport studies were performed using Caco- 2 cells, followed by quantification of the respective active ingredient using LC/ MS-MS. Furthermore, concomitant fluorescence anisotropy 
measurements were conducted to assess potential effects on membrane fluidity. In addition, ATPase assays were applied to investigate the substances' interaction with the active xenobiotic efflux transporter Pgp.

\section{Materials and methods}

\section{Test compounds}

Analytical grade abamectin (CAS no. 71751-41-2; batch no. BVBZ3693; purity 94.23\%), analytical grade fluroxypyrmeptyl (CAS no. 81406-37-3; batch no. BCBT2272; purity 98.5\%), analytical grade fluroxypyr (CAS no. 69377-81-7; batch no. BCCC5176; purity 99.1\%) and Tween ${ }^{\circledR} 80$ (CAS no. 9005-65-6; batch no. S7769787925) were obtained from Sigma-Aldrich (Taufkirchen, Germany). Soprophor ${ }^{\circledR}$ BSU (CAS no. 99734-09-5; batch no. 8361010), Soprophor $^{\circledR}$ 3D33 (CAS no. 90093-37-1; batch no. 8487267) and Rhodacal ${ }^{\circledR}$ 60/BE (CAS no. 26264-06-2/104-76-7; batch no. 52573L) were purchased from Solvay AG (Brussels, Belgium). Emulsogen ${ }^{\circledR}$ EL400 (CAS no. 61791-12-6; batch no. ESD0030925) was purchased from Clariant AG (Frankfurt am Main, Germany) and Solgad ${ }^{\circledR} 150$ ULN (CAS no. 64742-94-5; batch no. 0001201806) from OQEMA AG (Mönchengladbach, Germany). The PPPs were directly obtained from the manufacturer. Not all co-formulants contained in the PPPs were investigated individually, as their amounts in the products are negligible and/or they do not have any surface active properties. The composition information only on the investigated ingredients of the plant protection products are given in Table 1.

All test compounds were dissolved in dimethyl sulfoxide (DMSO; CAS no. 67-68-5; batch no. 80014081), purchased from Carl Roth (Karlsruhe, Germany), to result in a final solvent concentration of $0.4 \%(\mathrm{v} / \mathrm{v})$ in cell culture medium.

\section{Cell culture}

Caco-2 cells (ECACC: 86010202) were purchased from the European Collection of Authenticated Cell Cultures (Salisbury, UK). Caco-2 cells, passage 22-26, were grown and differentiated for three weeks in a culture medium, containing Dulbecco's Modified Eagle Medium (DMEM; PANBiotech GmbH, Aidenbach, Germany), supplemented with $10 \%$ standardized fetal calf serum (FCS Superior; Capricorn Scientific GmbH, Ebsdorfergrund, Germany), 100 U/ $\mathrm{mL}$ penicillin and $100 \mu \mathrm{g} / \mathrm{mL}$ streptomycin (PAA Laboratories $\mathrm{GmbH}$, Pasching, Austria). The cells were cultivated at $37{ }^{\circ} \mathrm{C}, 5 \% \mathrm{CO}_{2}$ and $5 \%$ humidity atmosphere in a cell culture incubator. They were passaged when reaching 80-90\% confluence every 2 to 3 days. Passaging was performed at maximum ten times and by aspirating the medium, washing with phosphate-buffered saline (PBS) and incubating with trypsin-EDTA (0.05\%) in Dulbecco's phosphate-buffered saline (Capricorn Scientific GmbH, Ebsdorfergrund, Germany) at $37^{\circ} \mathrm{C}$ for $3-5 \mathrm{~min}$. The incubation was stopped by DMEM supplemented with FCS Superior and the cells were separated by centrifugation.

\section{Cell viability}

Cytotoxicity was first analysed by water soluble tetrazolium assay (WST-1; Roche, Berlin, Germany), followed by neutral red uptake (NRU) assay. Caco- 2 cells were seeded in 96-well plates at a density of 5000 cells per well and differentiated for three weeks. The cells were incubated with both active substances and all of the above-mentioned co-formulants
Table 1 Composition information on the investigated ingredients of the plant protection products

\begin{tabular}{|c|c|c|}
\hline & Product 1 & Product 2 \\
\hline Active substance & $\begin{array}{l}\approx 2 \%(\mathrm{w} / \mathrm{w}) \text { abamectin } \\
\text { CAS-Nr.: } 71751-41-2 \\
\text { Containing } \geq 80 \% \text { avermectin } \mathrm{B}_{1 \mathrm{a}} \\
\text { and } \leq 20 \% \text { avermectin } \mathrm{B}_{1 \mathrm{~b}}\end{array}$ & $\begin{array}{l}\approx 30 \% \text { (w/w) fluroxypyr-meptyl } \\
\text { CAS-Nr.: } 81406-37-3\end{array}$ \\
\hline Investigated co-formulants & $\begin{array}{l}\approx 9 \%(\text { w/w) Tween } \\
{ }^{\circledR} 80 \\
\text { CAS-Nr.: } 9005-65-6 \\
\text { Polyoxyethylen-80-sorbitanmonooleat } \\
\text { Non-ionic surfactant } \\
\approx 2 \%\left(\text { w/w) Soprophor }{ }^{\circledR} \text { BSU }\right. \\
\text { CAS-Nr.: } 99734-09-05 \\
\text { Tristyrylphenol ethoxylate } \\
\text { Non-ionic surfactant } \\
\approx 2 \%\left(\text { w/w) Soprophor }{ }^{\circledR} 3 \mathrm{D} 33\right. \\
\text { CAS-Nr.: } 90093-37-1 \\
\text { Tristyrylphenol ethoxylate phosphate ester } \\
\text { Non-ionic surfactant }\end{array}$ & $\begin{array}{l}\approx 7 \%(\mathrm{w} / \mathrm{w}) \text { Emulsogen }{ }^{\circledR} \text { EL400 } \\
\text { CAS-Nr.: 61791-12-6 } \\
\text { Castor oil ethoxylate } \\
\text { Non-ionic surfactant } \\
\approx 4 \%(\mathrm{w} / \mathrm{w}) \text { Rhodacal }{ }^{\circledR} \text { 60/BE } \\
\text { CAS-Nr.: 26264-06-2/104-76-7 } \\
\text { Calcium dodecylbenzene } \\
\text { sulfonate } \\
\text { Anionic surfactant } \\
\approx 60 \% \text { (w/w) Solgad }{ }^{\circledR} 150 \text { ULN } \\
\text { CAS-Nr.: 64742-94-5 } \\
\text { Solvent naphtha (petroleum), } \\
\text { heavy aromatic (C9-C16) } \\
\text { Organic solvent }\end{array}$ \\
\hline
\end{tabular}


individually, with a combination of the active substances and the respective surfactants in a ratio in accordance with the products, as well as with the respective products, containing all co-formulants, for $24 \mathrm{~h}$. Eight different concentrations were investigated in culture medium with a final concentration of $0.4 \%$ DMSO. Triton X-100 (0.1\%) served as a positive control. After $24 \mathrm{~h}$ incubation a WST-1 assay was performed according to the protocol provided by the supplier.

Cytotoxicity was analysed by NRU assay according to the protocol by Repetto et al. (2008). In brief, medium was replaced by $100 \mu \mathrm{L}$ neutral red medium per well. Cells were incubated for $2 \mathrm{~h}$ at $37{ }^{\circ} \mathrm{C}$ and neutral red medium was removed. To extract the neutral red dye, $150 \mu \mathrm{L}$ of a solution (50\% ethanol/1\% acetic acid) was added per well and the plates were shaken for $10 \mathrm{~min}$ at room temperature. Absorbed dye was quantified by fluorescence measurement (Excitation $530 \mathrm{~nm}$; Emission $645 \mathrm{~nm}$ ) on an Infinite M200 PRO plate reader (Tecan, Maennedorf, Swiss). Signals were background corrected and viabilities were expressed as percentage of untreated cells. Each sample was measured in six replicates. Three independent experiments were performed $(n=3)$ and means, as well as standard deviations (SD) were calculated.

\section{Concentration-additivity modelling}

Dose-response modelling of concentration-additivity was used to examine the observed mixture effects, taking into account the cytotoxic effects of the investigated co-formulants. PROAST software ver. 70 was used to evaluate the nature of the observed mixture effects. Dose-response curves of the single compounds (active substances and coformulants) were used to model a theoretical mixture curve based on the assumption of dose addition. Following the methods of Kienhuis et al. (2015), we fitted a four parameter exponential model: $y=a \times\left[c-(c-1) \times \exp \left(-b \times x^{d}\right)\right]$ to the single substances that showed cytotoxic effects (abamectin, Soprophor ${ }^{\circledR}$ BSU and Soprophor ${ }^{\circledR} 3 \mathrm{D} 33$ for product 1; fluroxypyr-meptyl, Rhodacal ${ }^{\circledR}$ 60/BE and Solgad ${ }^{\circledR} 150$ ULN for product 2). Cytotoxicity dose-response data of mixtures and products were plotted in addition to the dose-response data of the respective single substances and their dose-response curve under the assumption of dose addition. The location of the plotted cytotoxicity dose-response data of the mixtures and the products were compared with the modelled dose-response curve under the assumption of dose addition (Kienhuis et al. 2015; Lasch et al. 2020).

\section{Fluorescence anisotropy}

The impact of the surface active co-formulants Tween ${ }^{\circledR} 80$, Soprophor ${ }^{\circledR}$ BSU, Soprophor ${ }^{\circledR}$ 3D33, Rhodacal ${ }^{\circledR}$ 60/BE and Emulsogen ${ }^{\circledR}$ EL 400 and the solvent Solgad ${ }^{\circledR} 150$ ULN on the membrane fluidity of the Caco-2 cells were assessed by measuring DPH fluorescence anisotropy, according to a method described earlier with minor modifications (Zeng et al. 2012). Furthermore, the active ingredients and the products were investigated at sub-cytotoxic concentrations to rule out any impact of the active ingredients. Briefly, Caco- 2 cells were cultivated in six-well plates for 21 days and detached on day 21 using $1 \mathrm{~mL}$ Accutase Cell Detachment Solution (ACC-1B, Capricorn Scientific GmbH, Ebsdorfergrund, Germany) per well. After incubation for 20-30 $\mathrm{min}$ at room temperature, detached cells were separated by centrifugation. Cells were resuspended in $2.5 \mathrm{~mL}$ of the test compounds or in $2.5 \mathrm{~mL}$ of the known membrane fluidizer benzyl alcohol (final concentration $60 \mathrm{mM}$; positive control) and incubated for $1 \mathrm{~h}$ at $37^{\circ} \mathrm{C}$. Afterwards Caco- 2 cell suspensions $\left(2 \times 10^{5}\right.$ cells $\left./ \mathrm{ml}\right)$ were labelled by adding $5 \mu \mathrm{L}$ of $1 \mathrm{mM}$ 1,6-diphenyl-1,3,5-hexatriene (DPH) stock solution in tetrahydrofuran (THF) for $30 \mathrm{~min}$ at room temperature in darkness. Fluorescence anisotropy measurements were performed at $37^{\circ} \mathrm{C}$ using a dual monochromator fluorescence spectrometer (model LS 55, PerkinElmer, Rodgau, Germany) fitted with polarizing filters and a stirred cell. Samples were excited with $355 \mathrm{~nm}$ vertical polarised light and emission was measured at $430 \mathrm{~nm}$ in vertical and horizontal direction. Since fluorescence anisotropy is inversely related to membrane fluidity, decreased DPH fluorescence anisotropy implies an increased membrane fluidity. Three independent experiments were performed $(n=3)$. The fluorescence anisotropy $(r)$ is defined by following equation:

$r=\left(I_{V V}-G I_{V H}\right) /\left(I_{V V}+2 G I_{V H}\right)$

$\mathrm{I}_{\mathrm{VV}}$ : fluorescence intensity measured in direction parallel to the polarised exciting light. $\mathrm{I}_{\mathrm{VH}}$ : fluorescence intensity measured in direction perpendicular to the polarised exciting light.G: IVH/IHH; correction factor for the instrument.

\section{Pgp ATPase assay}

This study focused on potential effects on Pgp transporters. Additional transporters present in Caco-2 cell lines may lead to potential cross-reactivity, the respective assay hence relied on recombinant human Pgp transporters integrated in membrane fractions.

The surface active co-formulants and the solvent Solgad ${ }^{\circledR}$ 150 ULN were tested at sub-cytotoxic concentrations for Pgp inhibition after stimulation with verapamil. Abamectin was tested for Pgp inhibition with verapamil, as well as for substrate properties without verapamil, since abamectin has been described as a mammalian Pgp substrate with inhibitory properties at higher concentrations (Lespine et al. 2007). Furthermore, fluroxypyr-meptyl was tested for Pgp substrate properties. Pgp ATPase activity modulation was 
determined using the Pgp-Glo assay system (Promega, Madison, WI, USA) following the manufacturer's user protocol. Briefly, $25 \mu \mathrm{g}$ of recombinant human Pgp membrane in PgpGlo assay buffer was incubated with different concentrations of each active substance or co-formulant in combination with $200 \mu \mathrm{M}$ verapamil at $37^{\circ} \mathrm{C}$ for $5 \mathrm{~min}$. Furthermore, Pgp membrane was incubated with $100 \mu \mathrm{M} \mathrm{Na}_{3} \mathrm{VO}_{4}$ (selective inhibitor), $200 \mu \mathrm{M}$ verapamil (substrate) or Pgp-Glo assay buffer (negative control). $5 \mathrm{mM} \mathrm{MgATP}$ was added to each well and 96-well plates were incubated at $37{ }^{\circ} \mathrm{C}$ for $40 \mathrm{~min}$ to initiate the reaction. Luminescence of the remaining, unmetabolised ATP was initiated by adding $50 \mu \mathrm{l}$ of $25 \mathrm{mM}$ ATP detection reagent. After briefly shaking on a plate shaker, 96-well plates were incubated at room temperature for $20 \mathrm{~min}$. The luciferase generated luminescence signal was measured on an Infinite M200 PRO plate reader (Tecan, Maennedorf, Swiss). All measurements were corrected by subtraction of $\mathrm{Na}_{3} \mathrm{VO}_{4}$-treated signals (non Pgp ATPase activity) and represented as changes in luminescence signals ( $\triangle$ RLU). Basal Pgp ATPase activity is represented by the difference in luminescence signals between $\mathrm{Na}_{3} \mathrm{VO}_{4}$-treated samples and untreated samples. Changes in luminescence ( $\triangle \mathrm{RLU}$ ) caused by the co-formulants and abamectin incubated with verapamil were compared to $\Delta$ RLU caused by verapamil. $\triangle R L U$ values of the active ingredients (without verapamil) were compared to $\Delta R L U$ values of untreated samples (basal $\Delta$ RLU). Each condition was measured in four replicates $(n=4)$.

\section{Transport studies}

Transport studies were conducted to investigate possible effects on the epithelial integrity caused by co-formulants, potentially leading to increased intestinal uptake of the active ingredients. Accordingly, quantification of abamectin and fluroxypyr-meptyl using LC-MS/MS analysis was conducted. Since in preliminary measurements very low amounts of fluroxypyr-meptyl were quantified, due to high metabolic conversion, fluroxypyr as one known metabolite has also been quantified. The acid fluroxypyr is formed by ester hydrolysis and has also herbicidal properties.

Transport studies of the active substances were performed as shown in Fig. 1 in 12-well transwell plates with inserts of polycarbonate membranes, $1.12 \mathrm{~cm}^{2}$ growth area and $0.4 \mu \mathrm{m}$ pore size (Corning Incorporated, New York, USA). Caco-2 cells were seeded at a density of 50,000 cells onto inserts transferred into commercial 12-well plates and cultivated for 21 days at $37{ }^{\circ} \mathrm{C}, 5 \% \mathrm{CO}_{2}$ and $5 \%$ humidity atmosphere as described earlier (Stock et al. 2019). Culture medium was changed every two to three days.

21 days after seeding and 18-24 h after medium change, inserts were transferred back into transwell plates. Transport studies were performed in apical (AP) to basolateral (BL) direction (absorption) and in BL to AP direction (secretion). Cells were exposed to (A) $1 \mathrm{mg} / \mathrm{mL}$ active substance individually, (B) $1 \mathrm{mg} / \mathrm{mL}$ active substance and the respective surfactants in a ratio corresponding to the products (mix $1 \mathrm{~A}$ and $\mathrm{mix} 2 \mathrm{~A}$ ), (C) $1 \mathrm{mg} / \mathrm{mL}$ active substance and the respective surfactants in their highest individually sub-cytotoxic concentration (mix 1B and mix 2B) and (D) $1 \mathrm{mg} / \mathrm{mL}$ active substance in the respective product. Donor compartments were filled with $500 \mu \mathrm{L}$ (AP) or $1500 \mu \mathrm{L}$ (BL) of the compounds solved in phenol red-free culture medium, containing 0.4\% DMSO. Receiver compartments were filled with $500 \mu \mathrm{L}$ (AP) or $1500 \mu \mathrm{l}$ (BL) phenol red-free culture medium containing $0.4 \%$ DMSO.

Cells were incubated at $37{ }^{\circ} \mathrm{C}$ for $8 \mathrm{~h}$. Sample aliquots of $200 \mu \mathrm{L}(\mathrm{AP})$ or $600 \mu \mathrm{L}$ (BL) were taken from the receiver compartment at time intervals of 2, 4, 6 and $8 \mathrm{~h}$. Sample aliquots were replaced with fresh, pre-warmed phenol redfree culture medium containing $0.4 \%$ DMSO, to ensure sink conditions. Sample aliquots were stored at $-80{ }^{\circ} \mathrm{C}$ and analysed by LC-MS/MS. Each transport study was performed in triplicate $(n=3)$ and means, as well as SD were calculated.

\section{Cell layer integrity}

Cell layer integrity was monitored as a quality control by transepithelial electrical resistance (TEER) measurements and by fluorescein isothiocyanate-dextran (FITC-dextran) flux. A epithelial voltohmmeter with chopstick electrode (EVOM2, World Precision Instruments, Sarasota, USA) was used to measure TEER values as the electrical resistance between the AP and the BL side of the cell layer, as previously described (Lichtenstein et al. 2015). TEER measurements were performed at the beginning $(0 \mathrm{~h})$ and end $(8 \mathrm{~h})$ of each experiment. FITC-dextran flux was measured by adding $500 \mu \mathrm{L}$ of $1 \mathrm{mg} / \mathrm{mL} 10 \mathrm{kDa}$ FITC-dextran into the AP compartment. Its transport was measured after $22-24 \mathrm{~h}$ incubation at $37^{\circ} \mathrm{C}$ in the $\mathrm{BL}$ compartment by fluorescence measurement (Excitation $485 \mathrm{~nm}$; Emission $535 \mathrm{~nm}$ ) on an Infinite M200 PRO plate reader (Tecan, Maennedorf, Swiss). Apparent permeability coefficients (Papp) were calculated by the formula: $\mathrm{Papp}=(\Delta \mathrm{Q} / \Delta \mathrm{t}) \times(\mathrm{A} \times \mathrm{c} 0)^{-1}$ for each well as described in detail earlier by Lichtenstein et al. (2015). TEER values were measured after incubation with FITCdextran. A graphical visualisation of the cell layer integrity data can be found in the supplementary material (Fig. S2-3).

\section{Sample preparation}

BL and AP medium samples were prepared with a Quick, Easy, Cheap, Effective, Rugged and Safe (QuEChERS) method first described by Anastassiades et al. (2007). Minor modifications were performed here. In brief, (1) $90 \%$ of the sample aliquots ( $180 \mu \mathrm{L}$ or $540 \mu \mathrm{L})$ were added into $50 \mathrm{~mL}$ 
centrifuge tubes; (2) $5 \mathrm{~mL}$ of Mili-Q water were added; (3) $10 \mathrm{~mL}$ of acetonitrile (ACN) were added to abamectin containing samples/ $10 \mathrm{~mL}$ of $\mathrm{ACN}+10 \%$ formic acid (FA) were added to fluroxypyr-meptyl containing samples and the mixtures were shaken vigorously by a vortex mixer for $10 \mathrm{~min}$; (4) one Supel QuE Citrate Extraction Tube 55,227-U (Sigma-Aldrich, Taufkirchen, Germany) was added to abamectin containing samples/ 1 g sodium chloride and $4 \mathrm{~g}$ magnesium sulfate anhydrous were added to fluroxypyr-meptyl containing samples and centrifuge tubes were shaken immediately for $1 \mathrm{~min}$; (5) centrifuge tubes were shaken vigorously by a vortex mixer for $10 \mathrm{~min}$; (6) centrifuge tubes were centrifuged for $5 \mathrm{~min}$ at $3000 \mathrm{~g}$ and $10{ }^{\circ} \mathrm{C}$; (7) $7 \mathrm{ml}$ of the supernatant were transferred in $15 \mathrm{ml}$ centrifuge tubes and $\mathrm{ACN}$ was evaporated with a nitrogen evaporator EVA 1 Vis (VLM GmbH, Bielefeld, Germany). The dry residues were redissolved in $0.25 \mathrm{ml}$ of mobile phase (initial conditions) and transferred in autosampler vials for LC-MS/MS analysis.

\section{LC-MS/MS analysis}

Abamectin is a mixture that contains $\geq 80 \%$ avermectin B1a and $\leq 20 \%$ avermectin B1b. Preliminary measurements showed that the avermectin B1b signals after sample preparation were below the limit of quantification. Therefore, all signals relate to avermectin B1a only.

Chromatographic separation was performed on an Agilent 1260 series liquid chromatography system (Agilent Technologies, Heilbronn, Germany) equipped with a reversedphase Kinetex EVO C18 column $(100 \times 4.6 \mathrm{~mm}, 2.6$ particle size, Phenomenex, Aschaffenburg, Germany) in combination with a guard column (Security Guard ${ }^{\mathrm{TM}}$ ULTRA, Phenomenex, Aschaffenburg, Germany). The liquid chromatography system consists of a binary pump system (G1312B), degasser (G4225A), autosampler with thermostat (G1367E HiP ALS + G1330B), column oven (G1316A TCC) and an Instant Pilot controller (G4208A). The injection volume was set to $2 \mu \mathrm{L}$ and the flow rate was set to $0.5 \mathrm{~mL} / \mathrm{min}$ for avermectin B1a method and $0.3 \mathrm{~mL} / \mathrm{min}$ for fluroxypyrmeptyl method. The column oven was maintained at $30^{\circ} \mathrm{C}$. Gradient conditions for avermectin B1a analysis and for fluroxypyr-meptyl analysis can be found in the supplementary material (Table S1-2).

Analysis was carried out with an AB Sciex 6500 QTRAP system (Applied Biosystems, Toronto, Canada) equipped with an ESI source with positive and negative ionisation (positive: avermectin B1a and fluroxypyr-meptyl; negative: fluroxypyr) and multiple-reaction-monitoring mode. The operation parameters were as follows: ionspray voltage (IS) $5500 \mathrm{~V}$, entrance potential (EP) $10 \mathrm{~V}$, collision gas (CAD) medium, curtain gas (CUR) 40 psi, temperature of ion source (TEM) $400{ }^{\circ} \mathrm{C}$, nebulising gas/ ion source gas 1 (GS1) 20 psi and drying gas/ ion source gas 2 (GS2) 50 psi. Parent ions were isolated and fragmented for avermectin B1a or fluroxypyr-meptyl and fluroxypyr. For each $\mathrm{m} / \mathrm{z}$ transition, declustering potential (DP), collision energy (CE) and collision cell exit potential (CXP) were optimised to obtain the maximum intensities. Scheduled MRM detection window was set to $60 \mathrm{~s}$ and target scan time was set to $2.3251 \mathrm{~s}$ for avermectin B1a method and $1.1050 \mathrm{~s}$ for fluroxypyr-meptyl method. Parameters of detection are displayed in Table 2. Two $\mathrm{m} / \mathrm{z}$ transitions with the highest intensity were obtained for each analyte, using the ion ratio as confirmatory parameter. Each sample was injected twice. Analyst Software was used for the LC-MS/MS system control and MultiQuant Software was used for data analysis.

\section{Statistical analysis}

Graphical visualisation of the data was performed using Graphpad Prism software version 9.0.0 and statistical analysis was performed using $\mathrm{R}$ software version 4.0.3 ( $\mathrm{R}$ Core Team 2020). For cell viability, fluorescence anisotropy and Pgp ATPase assay data a linear mixed-effects ANOVA ( $\alpha=0.05$ ) described by Pinheiro and Bates (2000) followed by a post hoc Dunnett test of multiple comparisons of treatment groups vs. the control was used for statistical analysis.

Table 2 Parameters of detection

\begin{tabular}{lllllll}
\hline Analyte & Parent ion (m/z) & Product ions $(\mathrm{m} / \mathrm{z})$ & $\begin{array}{l}\text { Retention } \\
\text { time }(\mathrm{min})\end{array}$ & DP (V) & CE (V) & CXP (V) \\
\hline Avermectin B1a & 890.405 & 305.100 & $4: 43$ & 56 & 35 & 22 \\
& & 567.300 & & 56 & 19 & 40 \\
& & 95.000 & & 56 & 101 & 14 \\
Fluroxypyr-meptyl & 367.043 & 255.000 & $10: 51$ & 10 & 15 & 24 \\
& & 209.000 & & 10 & 31 & 14 \\
& & 181.000 & & 10 & 45 & 14 \\
Fluroxypyr & 252.781 & 194.700 & $3: 22$ & -10 & -14 & -21 \\
& & 232.800 & & -10 & -10 & -13 \\
& & 188.800 & & -10 & -20 & -17 \\
\hline
\end{tabular}


Calculations were performed using the R-packages nlme (Pinheiro et al. 2020) and multcomp (Hothorn et al. 2008).

For the transport studies a repeated measures linear mixed-effects ANOVA $(\alpha=0.05)$ described by Pinheiro and Bates (2000) followed by a post hoc comparison with holm adjustment of the estimated curves of the combinations and products with the curve of the respective reference compound (active substance) was performed. Calculations were performed with the R-packages nlme (Pinheiro et al. 2020) and phia (De Rosario-Martinez et al. 2015).

\section{Results}

\section{Cell viability}

Results of WST-1 assays using Caco- 2 cells and $24 \mathrm{~h}$ of incubation are shown in Fig. 2. Abamectin exhibited significant cytotoxic effects at $32 \mathrm{mg} / \mathrm{L}$ (about $85 \%$ viability). Product 1 exhibited significant and higher cytotoxic effects at $40 \mathrm{mg} / \mathrm{L}$ (about $40 \%$ viability) compared to abamectin. The respective mixture of the active substance and the surface active co-formulants (Tween ${ }^{\circledR} 80$, Soprophor ${ }^{\circledR}$ BSU and Soprophor ${ }^{\circledR}$ 3D33) in the same ratio as in the product exhibited already at $10 \mathrm{mg} / \mathrm{L}$ significant cytotoxic effects (about 20\% viability) and was consequently most cytotoxic.

The second active ingredient fluroxypyr-meptyl did not show significant cytotoxic effects over the tested concentration range $(\leq 960 \mathrm{mg} / \mathrm{L})$. The respective mixture of the active substance and the surface active co-formulants (Rhodacal ${ }^{\circledR}$ 60/BE and Emulsogen ${ }^{\circledR}$ EL400) in the same ratio as in the product exhibited cytotoxic effects at $460.8 \mathrm{mg} / \mathrm{L}$ (about $50 \%$ viability). Product 2 exhibited cytotoxic effects at lower concentrations compared to the mixture (about $60 \%$ viability at $80 \mathrm{mg} / \mathrm{L}$ ).

Tween ${ }^{\circledR} 80$ and Emulsogen ${ }^{\circledR}$ EL400 were not cytotoxic in the tested concentration range $(\leq 1280 \mathrm{mg} / \mathrm{L})$. Soprophor ${ }^{\circledR}$ BSU and Soprophor ${ }^{\circledR}$ 3D33 exhibited significant cytotoxic effects at $80 \mathrm{mg} / \mathrm{L}$, Rhodacal ${ }^{\circledR} 60 / \mathrm{BE}$ at $320 \mathrm{mg} / \mathrm{L}$ and Solgad ${ }^{\circledR} 150 \mathrm{ULN}$ at $2400 \mathrm{mg} / \mathrm{L}$.

Similar results were obtained with the NRU assay (a graphical visualisation can be found in Fig. S1 in the supplementary material).

\section{Concentration-additivity modelling}

Abamectin was the reference substance for product 1 . The relative potency factor (RPF) of Soprophor ${ }^{\circledR}$ 3D33 was determined to be 4.895 and the RPF of Soprophor ${ }^{\circledR}$ BSU was 5.678. We observe that the cytotoxicity dose-response data of the mixture of abamectin and the investigated coformulants (light blue cross-square) is located left of the modelled dose-response curve representing dose addition. This indicates an effect which is more than additive. Product 1 (red cross) is located to the right of the curve indicating an effect which is less than additive (see Fig. 3a).

For the second comparison fluroxypyr-meptyl is the reference substance; Rhodacal $^{\circledR}$ 60/BE had a RPF of 9.796 and Solgad $^{\circledR} 150$ ULN had a RPF of 0.6797 . Since all co-formulants of product 2 are investigated, the PPP corresponds with the mixture of fluroxypyr-meptyl and the co-formulants. We see that the dose-response data of the product is situated to the left of the dose-response curve. This indicates a more than additive effect of the mixture (see Fig. 3b).

\section{Fluorescence anisotropy}

Anisotropy values ( $r$ values) for untreated Caco- 2 cells labelled with DPH were about 0.150 .

Results of compounds of product 1 are presented in Fig. $4 \mathrm{a}$ and of product 2 in Fig. 4b. All investigated surface active co-formulants showed a statistically significant decrease in DPH fluorescence anisotropy. $120 \mathrm{mg} / \mathrm{L}$ of Tween ${ }^{\circledR} 80$ and $120 \mathrm{mg} / \mathrm{L}$ of Emulsogen ${ }^{\circledR}$ EL 400, both containing POE, caused a decrease in fluorescence anisotropy, resulting in mean $r$ values of 0.135 and 0.139 respectively. Furthermore, $40 \mathrm{mg} / \mathrm{L}$ of the POE containing co-formulants

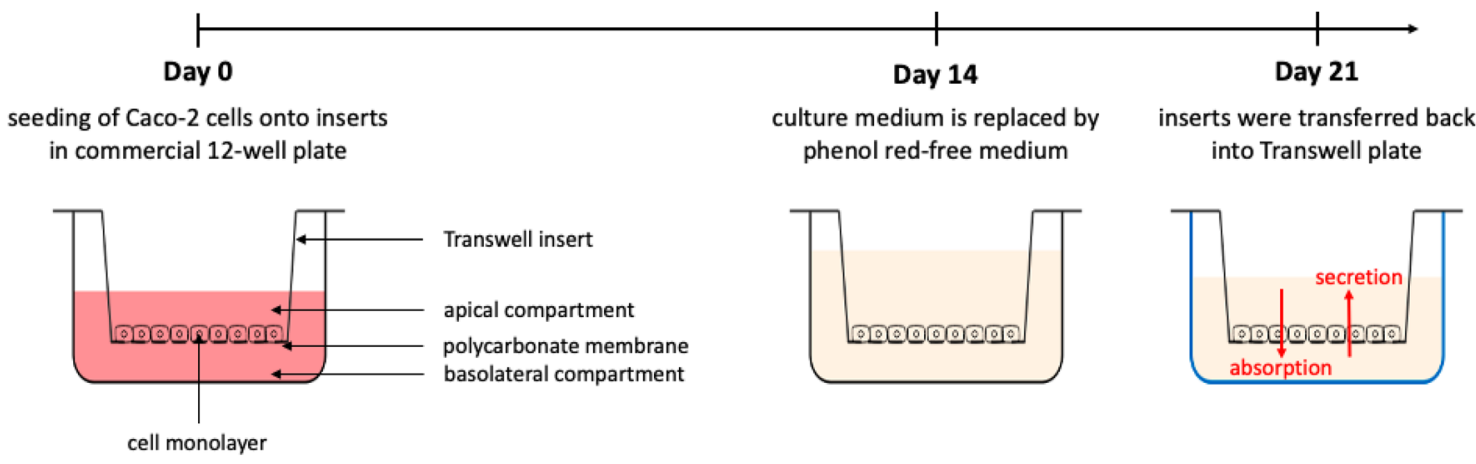

Fig. 1 Overview of cultivation and experimental conditions of the transport studies 
Fig. 2 Results of the WST-1 cytotoxicity assay in Caco-2 cells after $24 \mathrm{~h}$ exposure to increasing concentrations of a abamectin, product 1 and the respective mixture of abamectin and the investigated co-formulants in the same ration as in product 1, b fluroxypyr-meptyl, product 2 and the respective mixtures of fluroxypyr-meptyl and the investigated co-formulants in the same ratio as in the product $2, \mathbf{c}$ the investigated co-formulants of product 1 and d the investigated co-formulants of product 2 . Results are shown as percentage of the viability of the solvent control containing $0.4 \%$ DMSO. Concentrations of the mixtures and the PPPs refer to the concentration of the contained active ingredient. Mean values \pm SD of $n=3$ biological replicates, each performed with six technical replicates. Statistical analysis was done by a linear mixed-effects ANOVA ( $\alpha=0.05$ ) followed by a post hoc Dunnett test $(\alpha=0.05)$. Statistical significance compared to solvent control is indicated by asterisks (*)

\section{a}

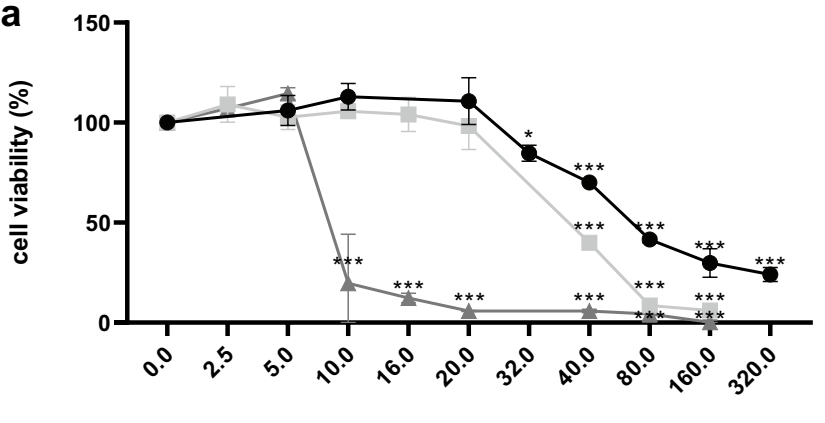

substance concentration (mg/L)

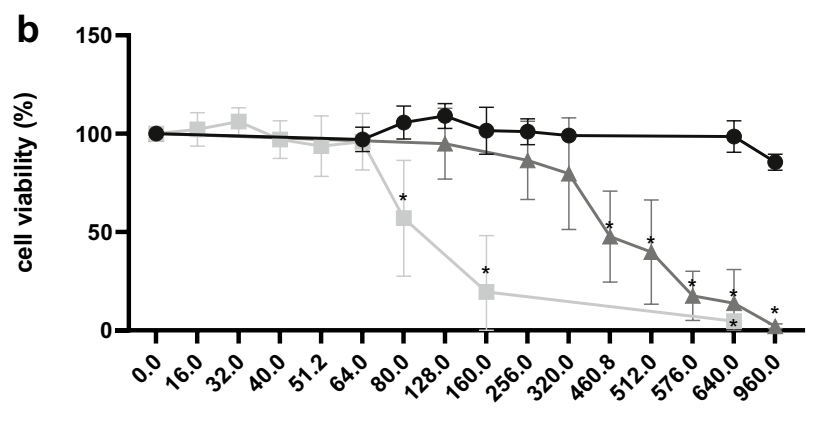

substance concentration (mg/L)

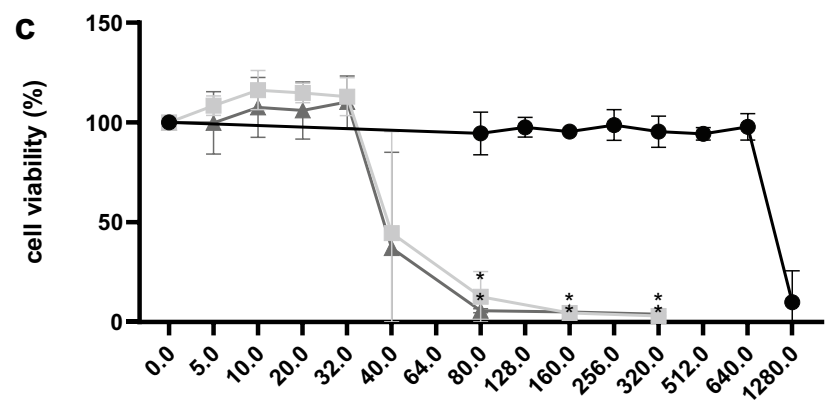

substance concentration (mg/L)

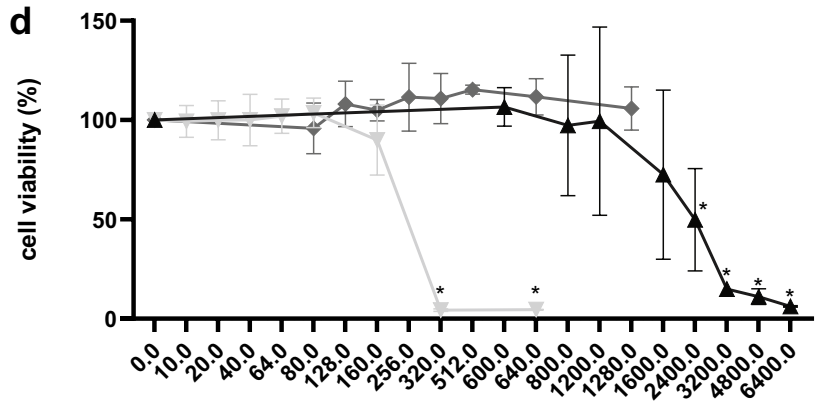

abamectin

product 1

abamectin + Tween $\AA 80$,

- Soprophor BSU, Soprophor ${ }^{\circledR} 3 D 33$

substance concentration (mg/L)

\ Solgad $(150$ ULN

Rhodacal® 60/BE

$\neg$ Emulsogen® EL400
Soprophor ${ }^{\circledR}$ BSU and Soprophor ${ }^{\circledR}$ 3D33 exhibited both a mean $r$ value of $0.135 .120 \mathrm{mg} / \mathrm{L}$ of the anionic surfactant Rhodacal $^{\circledR}$ 60/BE decreased the fluorescence anisotropy significantly compared to the untreated control at a mean $r$ value of 0.121 .
$10 \mathrm{mg} / \mathrm{L}$ of the active ingredient abamectin, $64 \mathrm{mg} / \mathrm{L}$ of the active ingredient fluroxypyr-meptyl as well as $160 \mathrm{mg} / \mathrm{L}$ of the solvent Solgad ${ }^{\circledR} 150$ ULN did not show a statistically significant impact on the fluorescence anisotropy. However, product 1 (containing $10 \mathrm{mg} / \mathrm{L}$ abamectin) and product 2 

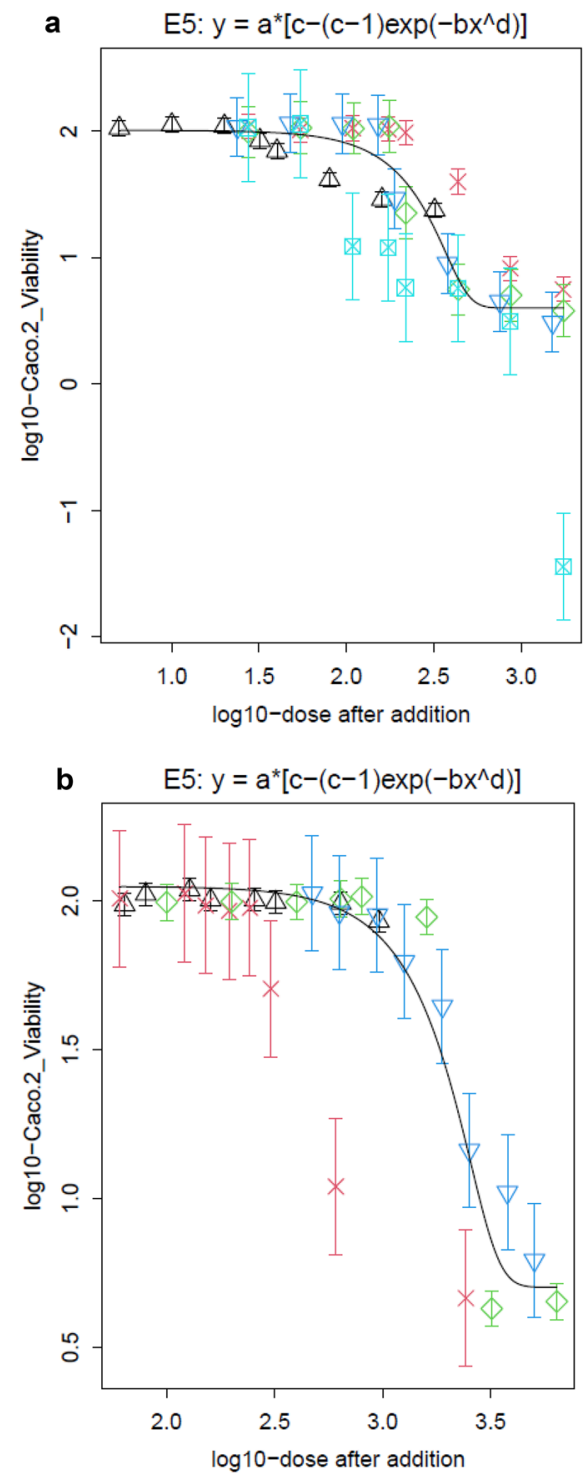

Fig. 3 Concentration-response modelling of the cytotoxicity in Caco-2 cells of a abamectin (black upward triangle), Soprophor ${ }^{\circledR}$ BSU (dark blue downward triangle), Soprophor ${ }^{\circledR}$ 3D33 (green diamond), product 1 (red cross), combination of abamectin and respective co-formulants (light blue cross-square) and b fluroxypyr-meptyl (black upward triangle), Rhodacal $^{\circledR}$ 60/BE (green diamond), Solgad ${ }^{\circledR}$ 150 ULN (dark blue downward triangle) and product 2 (red cross). The black lines are representing the dose-response curves of the mixtures under the assumption of dose addition of the single substances. Modelling was performed using the PROAST software ver. 70 (color figure online)

(containing $64 \mathrm{mg} / \mathrm{L}$ fluroxypyr-meptyl) exhibited significantly decreased $r$ values of 0.116 and 0.117 , respectively. In conclusion, the products showed the highest impact on the DPH fluorescence anisotropy.

Since all co-formulants of product 2 are examined here, the increased membrane fluidity caused by the product can be attributed to the surface active co-formulants. Product 1 contains additional, not investigated co-formulants. Since the membrane fluidity is still increased compared to the untreated control, the other co-formulants do not seem to compensate this effect.

\section{Pgp ATPase assay}

As shown in Fig. 5a, abamectin statistical significantly stimulated Pgp ATPase activity only at the lowest concentration of $1.25 \mathrm{mg} / \mathrm{L}$ by approximately $250 \%$ compared to the untreated control. Fluroxypyr-meptyl did not show a significant impact on the ATPase activity.

At higher concentrations (2.5-64 mg/L) abamectin inhibited in a concentration-dependent manner the verapamilstimulated Pgp ATPase activity with a maximum decreased $\Delta$ RLU value of $30 \%$ compared to the verapamil control (Fig. 5b).

All investigated surfactants, except for Tween ${ }^{\circledR} 80$, showed inhibition of verapamil-stimulated Pgp ATPase activity in a concentration-dependent manner (Fig. 5c-f). Soprophor ${ }^{\circledR}$ BSU and Soprophor ${ }^{\circledR}$ 3D33 exhibited statistically significant decreased $\triangle \mathrm{RLU}$ values at lowest concentrations of $2.5 \mathrm{mg} / \mathrm{L}$ and $5 \mathrm{mg} / \mathrm{L}$, respectively. Emulsogen ${ }^{\circledR}$ EL 400 and Rhodacal ${ }^{\circledR}$ 60/BE decreased $\triangle$ RLU values at lowest concentrations of $20 \mathrm{mg} / \mathrm{L}$. Furthermore, Solgad ${ }^{\circledR}$ 150 ULN did not show significant inhibition of verapamilstimulated Pgp ATPase activity.

In summary, four of five investigated surfactants are suggested to cause higher bioavailability of Pgp substrates (i.e. abamectin at low concentrations) due to Pgp ATPase inhibition. A graphical visualisation of the fluorescence anisotropy data for fluroxypyr-meptyl, Tween ${ }^{\circledR} 80$ and Solgad ${ }^{\circledR} 150$ ULN can be found in the supplementary material (Fig. S4).

\section{Transport studies}

The relative transported amount of avermectin B1a in \% over an incubation time of $8 \mathrm{~h}$ in both directions is shown in Fig. 6. In AP-BL direction, over an incubation time of $8 \mathrm{~h}$ with mix $1 \mathrm{~A}$ significantly more avermectin B1a was absorbed compared to the transport studies with $1 \mathrm{mg} / \mathrm{L}$ of abamectin. After AP incubation with product 1 containing $1 \mathrm{mg} / \mathrm{L}$ abamectin, the same, but no significant trend was observed. In contrast, over $8 \mathrm{~h}$ of incubation with mix 1B, containing higher concentrations of the surfactants, less avermectin B1a was absorbed (Fig. 6a). In BL-AP direction, transport studies with all combinations (mix 1A, product 1 and mix 1B) resulted in significantly lower secretion of avermectin B1a, compared to those of abamectin alone (see Fig. 6b).

When comparing the $\mathrm{AP}-\mathrm{BL}$ and $\mathrm{BL}-\mathrm{AP}$ transport studies after $8 \mathrm{~h}$ of incubation, it was found that the studies with abamectin resulted in almost the same relative 
a

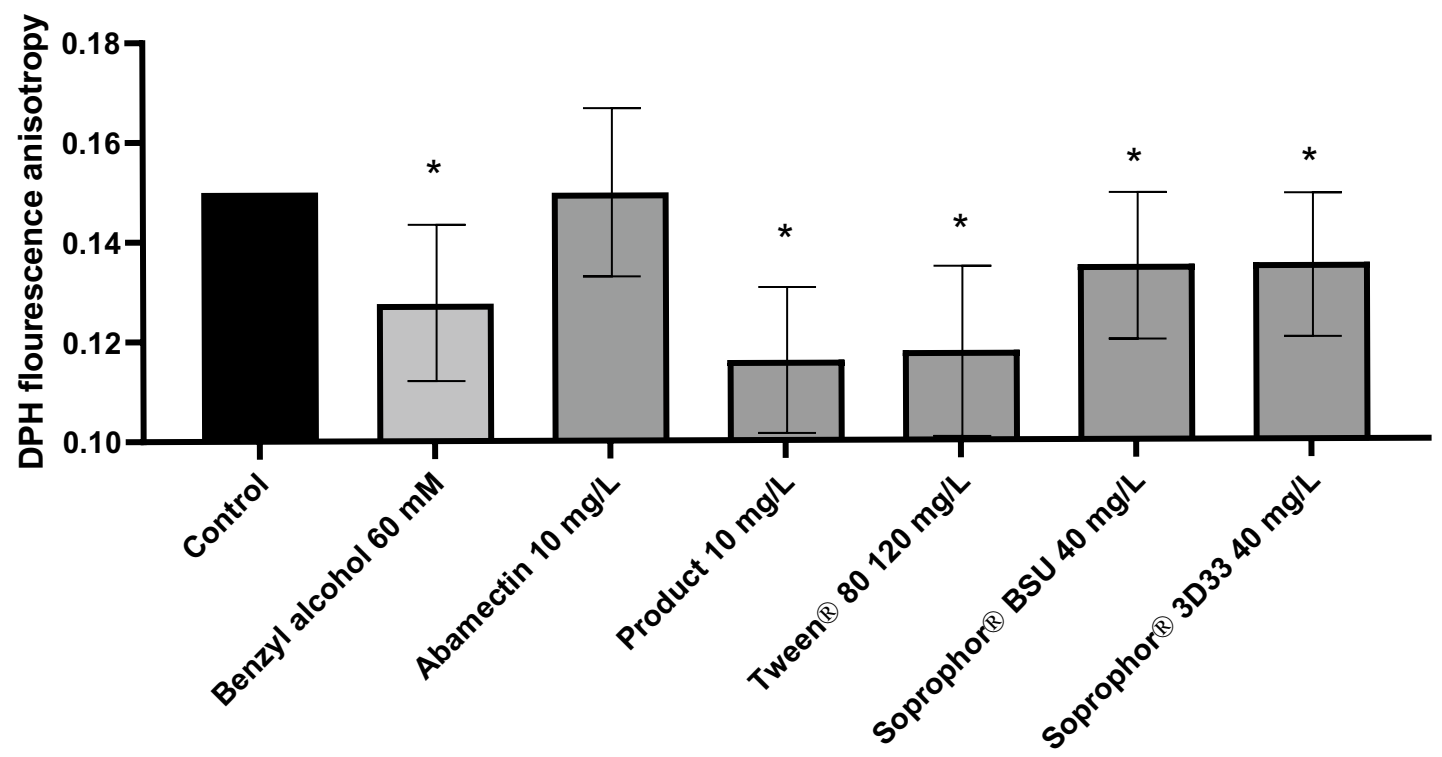

b

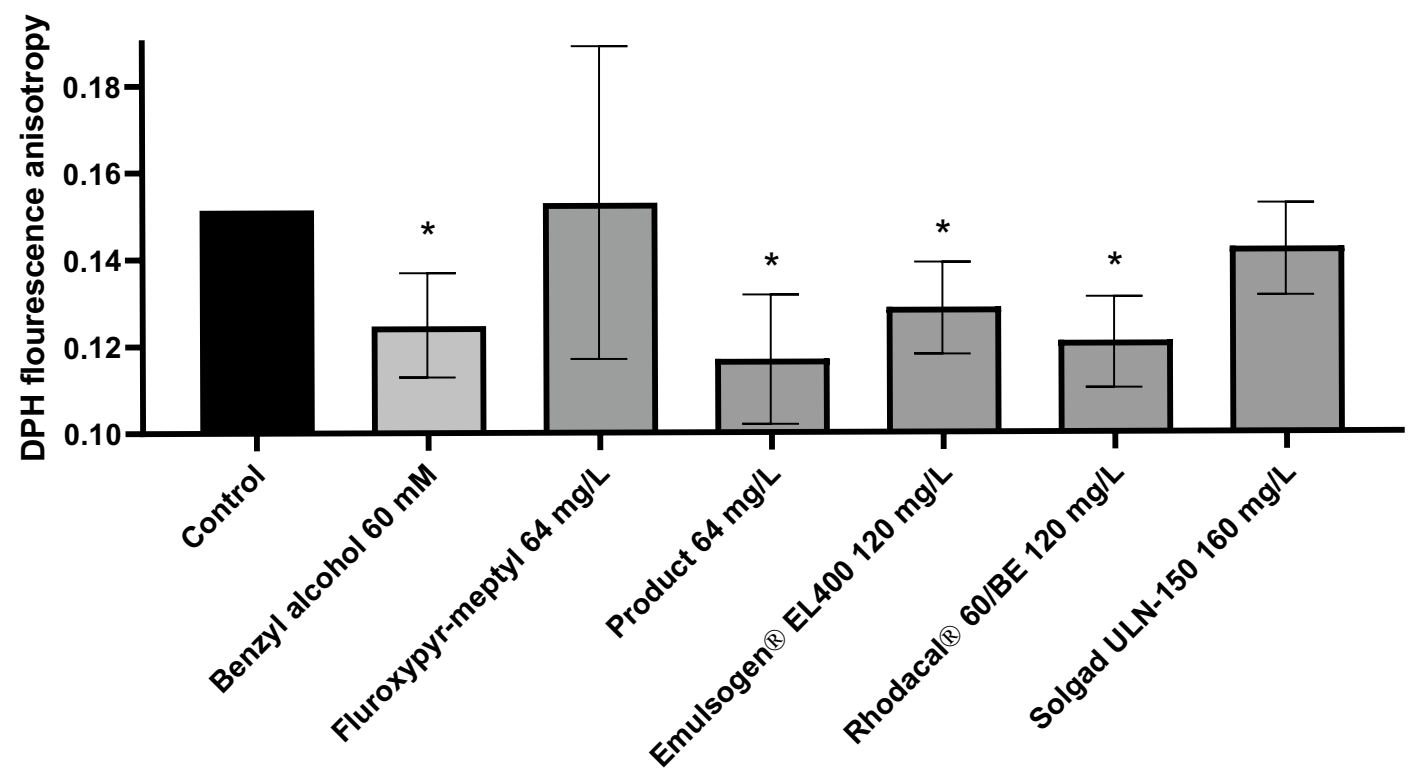

Fig. 4 Alteration in Caco-2 cell membrane fluidity assessed using DPH fluorescence anisotropy after treatment with a abamectin, product 1 , Tween ${ }^{\circledR} 80$, Soprophor ${ }^{\circledR}$ BSU and Soprophor ${ }^{\circledR} 3$ D33 and b fluroxypyr-meptyl, product 2, Rhodacal ${ }^{\circledR}$ 60/BE, Emulsogen ${ }^{\circledR} \mathrm{EL}$ 400 and Solgad ${ }^{\circledR} 150$ ULN. Benzyl alcohol $60 \mathrm{mM}$ served as a positive control. Data are presented as mean values of $n=3$ biological

replicates, each performed with two technical replicates. Error bars indicate confidence intervals obtained from statistical analysis using a two-sided post hoc Dunnett test $(\alpha=0.05)$, with a preceding linear mixed-effects ANOVA test $(\alpha=0.05)$. Statistical significance compared to untreated control is indicated by asterisks $(*)$

amounts of avermectin B1a in the BL compartment with $23.96 \% \pm 0.29 \%$ and in the AP compartment with $21.27 \% \pm 3.85 \%$ (see Fig. 7). Consequently, the BL-AP versus AP-BL ratio (efflux ratio) was close to 1 with a value of 0.888 . Contrary, incubation with all combinations (mix $1 \mathrm{~A}$, product 1 and mix $1 \mathrm{~B}$ ) resulted in significantly higher amounts of avermectin B1a in the BL compartment compared to the AP compartment, suggesting higher absorption than secretion. The lowest efflux ratio was found for product 1 with 0.413 , resulted by $27.99 \% \pm 4.11 \%$ transported avermectin B1a amount in AP-BL direction and $11.56 \pm 1.52 \%$ in BL-AP direction. Nearly the same efflux ratio was observed for mix $1 \mathrm{~A}$ with 0.418 , corresponding to $32.45 \% \pm 0.29 \%$ of avermectin $\mathrm{B} 1 \mathrm{a}$ in $\mathrm{AP}-\mathrm{BL}$ direction and $13.57 \% \pm 0.70 \%$ in $\mathrm{BL}-\mathrm{AP}$ direction. For mix $1 \mathrm{~B}$ in AP-BL direction $19.23 \% \pm 3.59 \%$ and in $\mathrm{BL}-\mathrm{AP}$ direction $12.29 \% \pm 2.04 \%$ avermectin $\mathrm{B} 1 \mathrm{a}$ was measured, leading to an efflux ratio of 0.636 . 
a

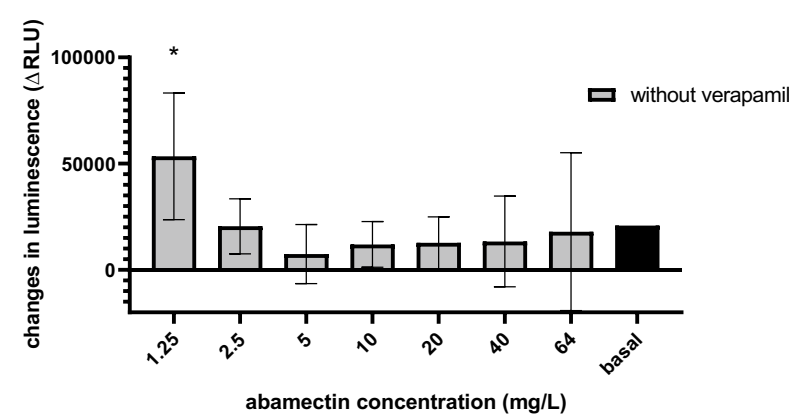

C

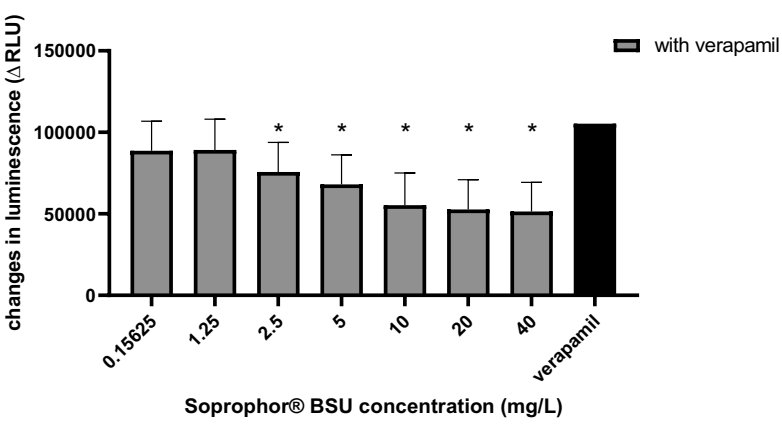

e

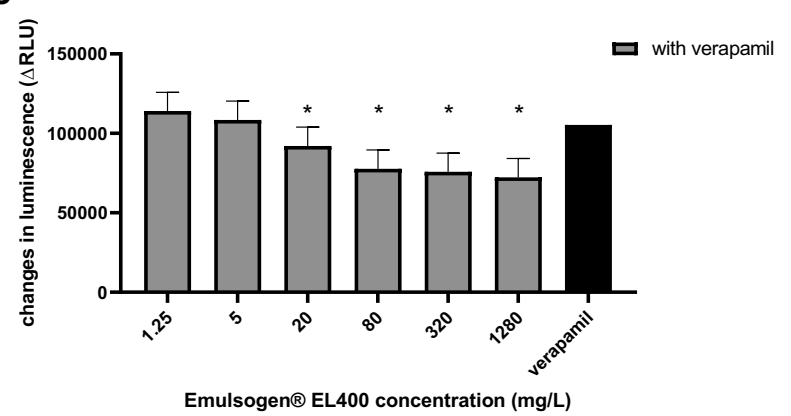

Fig. 5 Pgp ATPase activity presented as changes in luminescence $\triangle$ RLU of (a) abamectin compared to untreated samples (basal) and (b-f) abamectin, Soprophor ${ }^{\circledR}$ BSU, Soprophor ${ }^{\circledR} 3$ D33, Emulsogen ${ }^{\circledR}$ EL 400 and Rhodacal ${ }^{\circledR}$ 60/BE after stimulation with verapamil compared to verapamil control. All measurements were corrected by subtraction of $\mathrm{Na}_{3} \mathrm{VO}_{4}$-treated signals (non Pgp ATPase activity). Data are presented as mean values of $n=4$ independent experiments. Error

The relative transported amount of fluroxypyr-meptyl and its metabolite fluroxypyr over an incubation time of $8 \mathrm{~h}$ in both directions is shown in Fig. 8. In AP-BL direction, incubation with mix $2 \mathrm{~B}$ resulted in a significantly higher absorption of fluroxypyr-meptyl and fluroxypyr compared to the transport studies with $1 \mathrm{mg} / \mathrm{L}$ of fluroxypyr-meptyl. Mix $2 \mathrm{~A}$ and product 2 , both containing lower concentrations of the surfactants, did not show a significant difference of the transported fluroxypyr-meptyl amount compared to transport studies incubated with fluroxypyr-meptyl alone (Fig. 8a). In contrast, after incubation with mix $2 \mathrm{~A}$ and product 2 in AP-BL direction a higher relative amount of the metabolite b

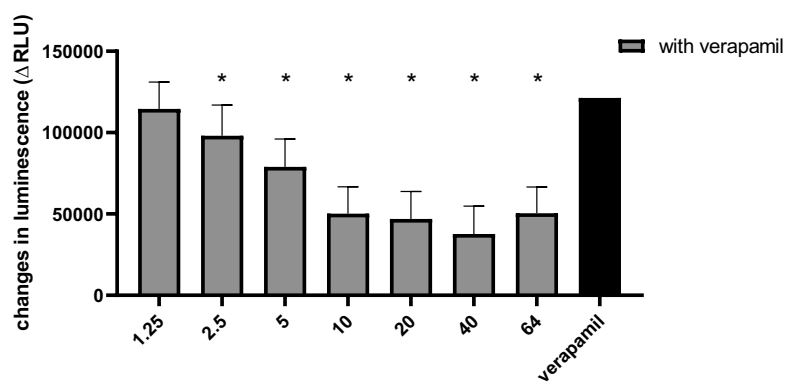

abamectin concentration ( $\mathrm{mg} / \mathrm{L}$ )

d
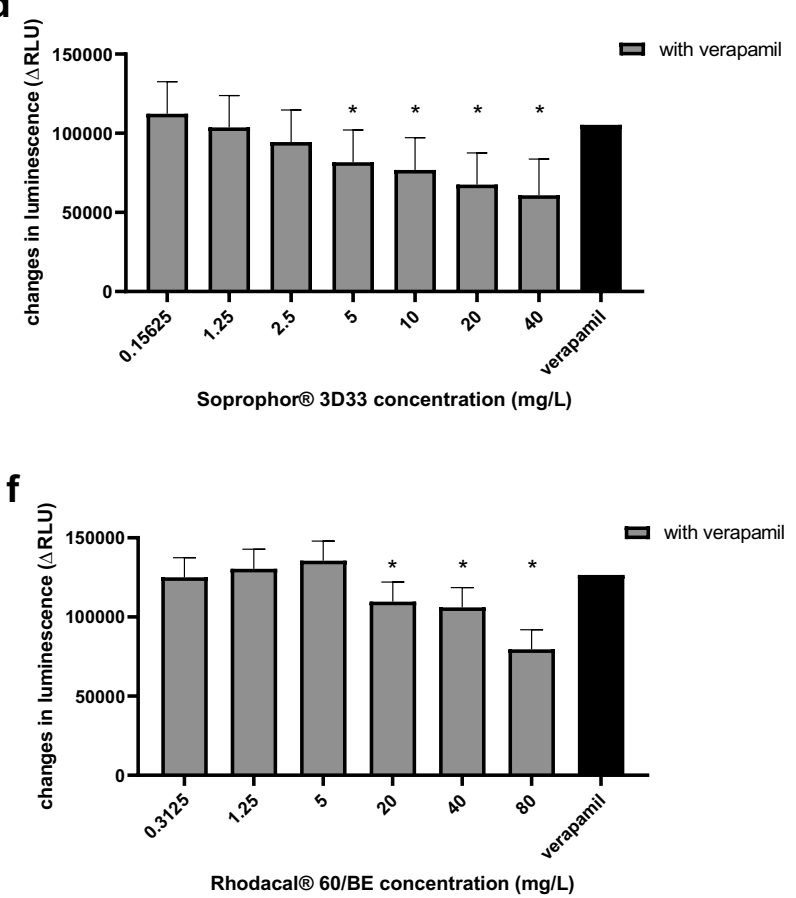

bars indicate confidence intervals obtained from statistical analysis using an either two-sided (error bars in both direction) or one-sided (error bars in one direction) post hoc Dunnett test $(\alpha=0.05)$, with a preceding linear mixed-effects ANOVA test $(\alpha=0.05)$. Statistical significance compared to untreated control/verapamil control is defined by asterisks $(*)$

fluroxypyr was measured than in fluroxypyr-meptyl transport studies (Fig. 8c).

Furthermore, in BL-AP direction, incubation with all combinations and the active ingredient individually resulted in comparable transported fluroxypyr-meptyl amounts (Fig. 8b). Similar results were found for the metabolite, except for the results after incubation with mix 2B. Significantly less fluroxypyr was secreted over $8 \mathrm{~h}$ of incubation with mix $2 \mathrm{~B}$ compared to transport studies with the active ingredient (Fig. 8d).

When comparing the $\mathrm{AP}-\mathrm{BL}$ and $\mathrm{BL}-\mathrm{AP}$ direction after $8 \mathrm{~h}$, incubation with all treatments resulted in higher 
Fig. 6 Results of transport studies presented as cumulative transported amounts of avermectin $\mathrm{B} 1 \mathrm{a}$ in a $\mathrm{AP}-\mathrm{BL}$ direction and $\mathbf{b}$ BL-AP direction. Transport studies in both directions were carried out with $1 \mathrm{mg} / \mathrm{L}$ abamectin, $\operatorname{mix} 1 \mathrm{~A}(1 \mathrm{mg} / \mathrm{L}$ abamectin $+4.2 \mathrm{mg} / \mathrm{L}$ Tween ${ }^{\circledR} 80$, $1 \mathrm{mg} / \mathrm{L}$ Soprophor ${ }^{\circledR}$ BSU, $1 \mathrm{mg} / \mathrm{L}$ Soprophor ${ }^{\circledR}$ 3D33), product 1 (containing $1 \mathrm{mg} / \mathrm{L}$ abamectin) and mix $1 \mathrm{~B}(1 \mathrm{mg} / \mathrm{L}$ abamectin $+80 \mathrm{mg} / \mathrm{L}$ Tween ${ }^{\circledR}$ $80,40 \mathrm{mg} / \mathrm{L}$ Soprophor ${ }^{\circledR} \mathrm{BSU}$, $40 \mathrm{mg} / \mathrm{L}$ Soprophor ${ }^{\circledR}$ 3D33). All concentrations were related to the measured start concentrations of the solutions and are given as relative values in percent. Data are presented as mean values $\pm \mathrm{SD}$ of $n=3$ independent experiments. Statistical analysis was conducted by a linear mixed-effects ANOVA ( $\alpha=0.05$ ) followed by a post hoc comparison with holm adjustment of the estimated curves of mix $1 \mathrm{~A}$, product 1 and mix $1 \mathrm{~B}$ with the curve of the active ingredient abamectin. Statistical significance at $\alpha=0.05$ level compared to reference compound is indicated by asterisks $(*)$ a

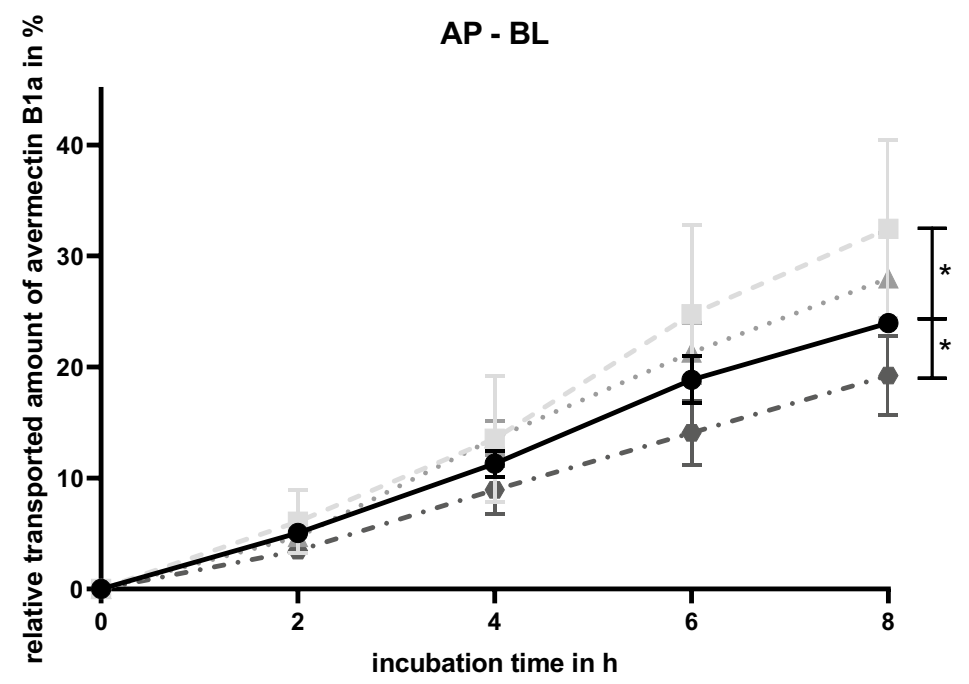

abamectin $1 \mathrm{mg} / \mathrm{L}$ mix $1 \mathrm{~A} 1 \mathrm{mg} / \mathrm{L}$ - product $11 \mathrm{mg} / \mathrm{L}$ - $\operatorname{mix} 1 \mathrm{~B} 1 \mathrm{mg} / \mathrm{L}$

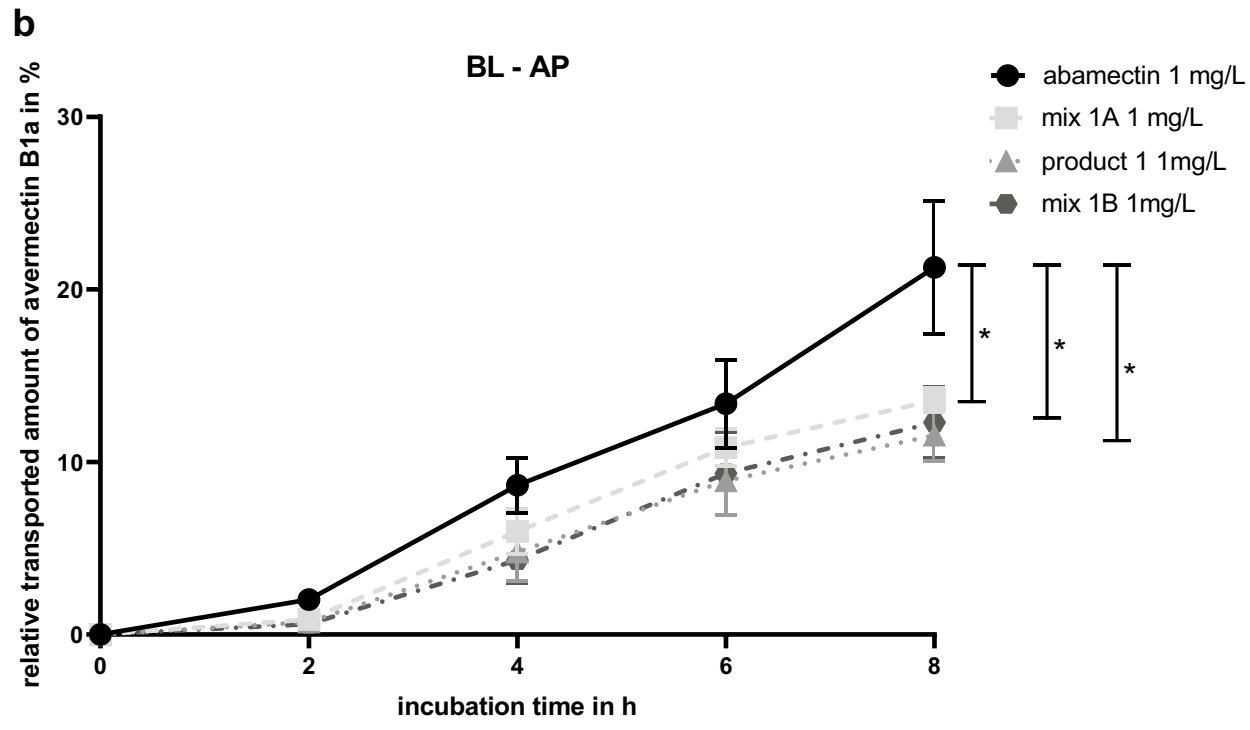

amounts of fluroxypyr-meptyl in the BL compartment compared to the AP compartment. The lowest efflux ratio of 0.089 was found for mix 2B with $0.271 \% \pm 0.011 \%$ of fluroxypyr-meptyl in AP-BL direction and $0.024 \% \pm 0.008 \%$ in BL-AP direction. $0.132 \% \pm 0.014 \%$ of fluroxypyr-meptyl was obtained after incubation with the active ingredient individually in AP-BL direction and $0.025 \% \pm 0.006 \%$ in BL-AP direction, resulting in an efflux ratio of 0.189 . For mix $2 \mathrm{~A}$ and product 2 similar efflux ratios of 0.164 and 0.193 were obtained, respectively (Fig. 9a).

Notably, comparing fluroxypyr amounts in AP-BL and $\mathrm{BL}-\mathrm{AP}$ direction, incubation with the active ingredient individually, mix $2 \mathrm{~A}$ and product 2 showed higher amounts of the metabolite in $\mathrm{BL}-\mathrm{AP}$ direction than in AP-BL direction. $2.107 \% \pm 0.017 \%$ of fluroxypyr was obtained after incubation with fluroxypyr-meptyl in AP-BL direction and $3.614 \% \pm 1.079 \%$ in BL-AP direction, resulting in a flux of 1.715. For mix $2 \mathrm{~A}$ and product 2 similar efflux ratios of 1.683 and 1.958 were found, respectively. Only mix 2B showed higher amounts of fluroxypyr in AP-BL direction $(2.624 \% \pm 0.447 \%)$ compared to $\mathrm{BL}-\mathrm{AP}$ direction $(2.011 \% \pm 0.050 \%)$, resulting in an efflux ratio of 0.763 (Fig. 9b).

\section{Discussion}

The aim of this work was to investigate mixture effects of surface active co-formulants and active substances in PPPs on the toxicokinetic level due to altered absorption and/or secretion. To address this issue, two PPPs were selected, containing several surface active co-formulants. Our results show that the surface active co-formulants investigated in this work exhibit toxicokinetic interactions 
Fig. 7 Comparison of the cumulative transported amount of avermectin B1a in \% after $8 \mathrm{~h}$ of incubation in AP-BL and BL-AP direction carried out with $1 \mathrm{mg} / \mathrm{L}$ abamectin, $\operatorname{mix} 1 \mathrm{~A}(1 \mathrm{mg} / \mathrm{L}$ abamectin $+4.2 \mathrm{mg} / \mathrm{L}$ Tween ${ }^{\circledR} 80$, $1 \mathrm{mg} / \mathrm{L}$ Soprophor ${ }^{\circledR}$ BSU, $1 \mathrm{mg} / \mathrm{L}$ Soprophor $\left.{ }^{\circledR} 3 \mathrm{D} 33\right)$, product 1 (containing $1 \mathrm{mg} / \mathrm{L}$ abamectin) and mix 1B (1 mg/L abamectin $+80 \mathrm{mg} / \mathrm{L}$ Tween ${ }^{\circledR}$ $80,40 \mathrm{mg} / \mathrm{L}$ Soprophor ${ }^{\circledR} \mathrm{BSU}$, $40 \mathrm{mg} / \mathrm{L}$ Soprophor ${ }^{\circledR}$ 3D33). Data are presented as mean values $\pm \mathrm{SD}$ of $n=3$ independent experiments

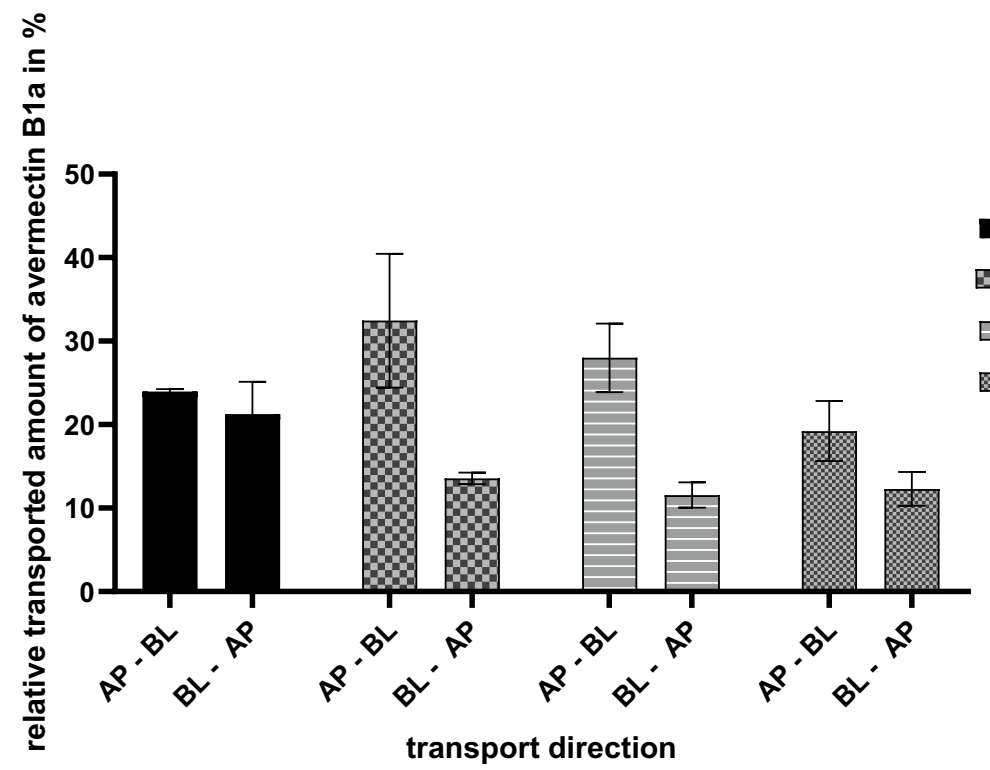

abamectin $1 \mathrm{mg} / \mathrm{L}$ 파 $\mathrm{mix} 1 \mathrm{~A} 1 \mathrm{mg} / \mathrm{L}$ product $11 \mathrm{mg} / \mathrm{L}$ mix 1B 1mg/L
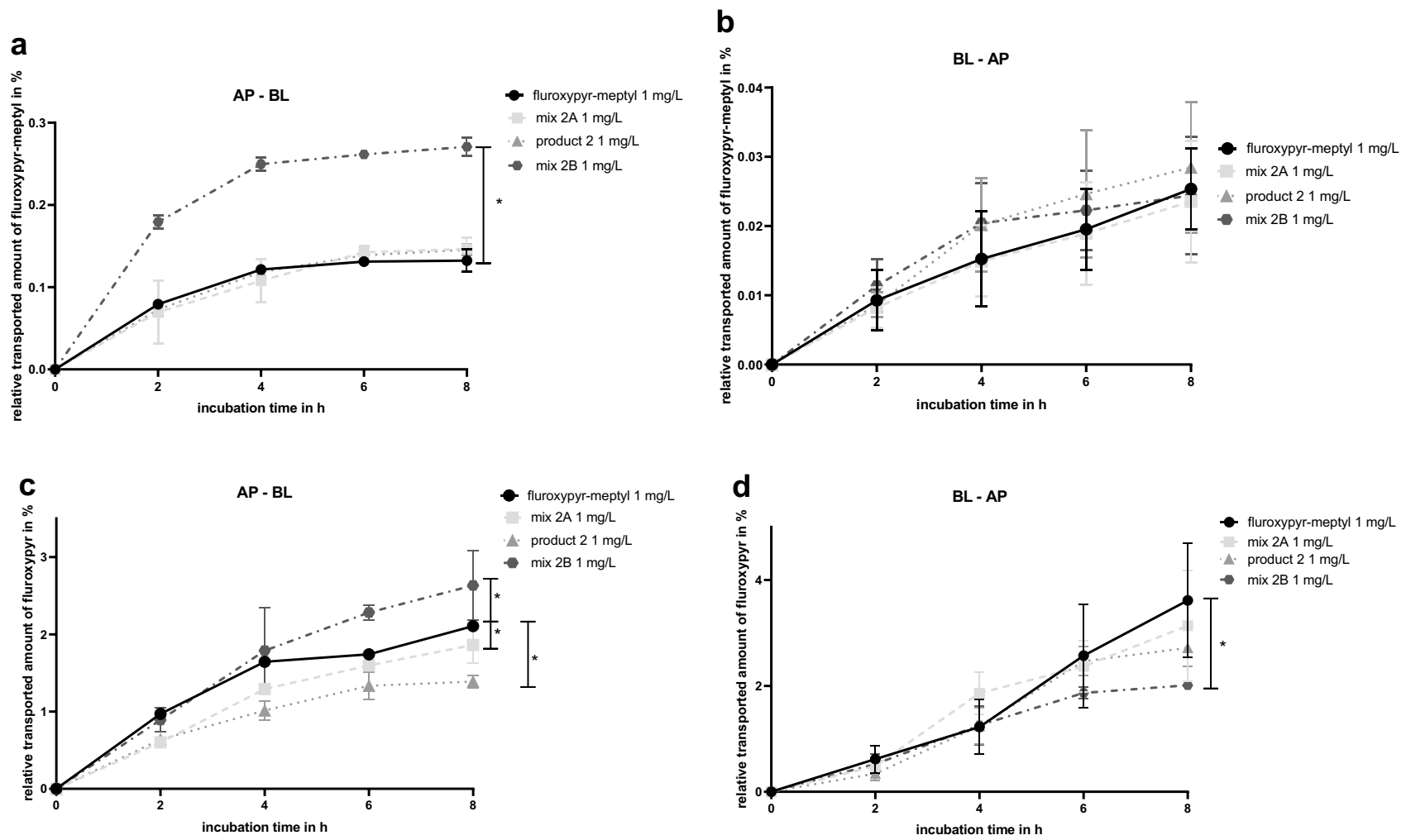

Fig. 8 Results of transport studies presented as cumulative transported amounts of fluroxypyr-meptyl in a AP-BL direction and b BL-AP direction and fluroxypyr in $\mathbf{c}$ AP-BL direction and $\mathbf{d}$ BL-AP direction. Transport studies in both directions were carried out with $1 \mathrm{mg} / \mathrm{L}$ fluroxypyr-meptyl, mix $2 \mathrm{~A}$ (1 mg/L fluroxypyrmeptyl+0.1 mg/L Rhodacal ${ }^{\circledR}$ 60/BE, 0.2 mg/L Emulsogen ${ }^{\circledR}$ EL400), product 2 (containing $1 \mathrm{mg} / \mathrm{L}$ fluroxypyr-meptyl) and mix 2B (1 mg/L abamectin $+120 \mathrm{mg} / \mathrm{L}$ Rhodacal ${ }^{\circledR}$ 60/BE, $120 \mathrm{mg} / \mathrm{L}$ Emulsogen ${ }^{\circledR}$ EL400, $160 \mathrm{mg} / \mathrm{L}$ Solgad $\left.{ }^{\circledR} 150 \mathrm{ULN}\right)$. All concentrations were related to the measured start concentrations of the solu-

tions and are given as relative values in percent. Data are presented as mean values \pm SD of $n=2$ independent experiments for AP-BL direction and $n=3$ independent experiments for BL-AP direction. Statistical analysis was done by a linear mixed-effects ANOVA $(\alpha=0.05)$ followed by a post hoc comparison with holm adjustment of the estimated curves of mix $2 \mathrm{~A}$, product 2 and mix $2 \mathrm{~B}$ with the curve of the active ingredient fluroxypyr-meptyl. Statistical significance at $\alpha=0.05$ level compared to reference compound is indicated by asterisks $(*)$ 
Fig. 9 Comparison of the cumulative transported amount of a fluroxypyr-meptyl and b fluroxypyr in \% after $8 \mathrm{~h}$ of incubation in AP-BL and BL-AP direction carried out with $1 \mathrm{mg} / \mathrm{L}$ fluroxypyr-meptyl, mix $2 \mathrm{~A}(1 \mathrm{mg} / \mathrm{L}$ fluroxypyrmeptyl $+0.1 \mathrm{mg} / \mathrm{L}$ Rhodacal ${ }^{\circledR}$ 60/BE, $0.2 \mathrm{mg} / \mathrm{L}$ Emulsogen ${ }^{\circledR}$ EL400), product 2 (containing $1 \mathrm{mg} / \mathrm{L}$ fluroxypyr-meptyl) and mix $2 \mathrm{~B}(1 \mathrm{mg} / \mathrm{L}$ abamectin $+120 \mathrm{mg} / \mathrm{L}$ Rhodacal $^{\circledR} 60 /$ BE, $120 \mathrm{mg} / \mathrm{L}$ Emulsogen ${ }^{\circledR}$ EL400, $160 \mathrm{mg} / \mathrm{L}$ Solgad ${ }^{\circledR} 150$ ULN). Data are presented as mean values \pm SD of $n=2$ independent experiments for AP-BL direction and $n=3$ independent experiments for $\mathrm{BL}-\mathrm{AP}$ direction
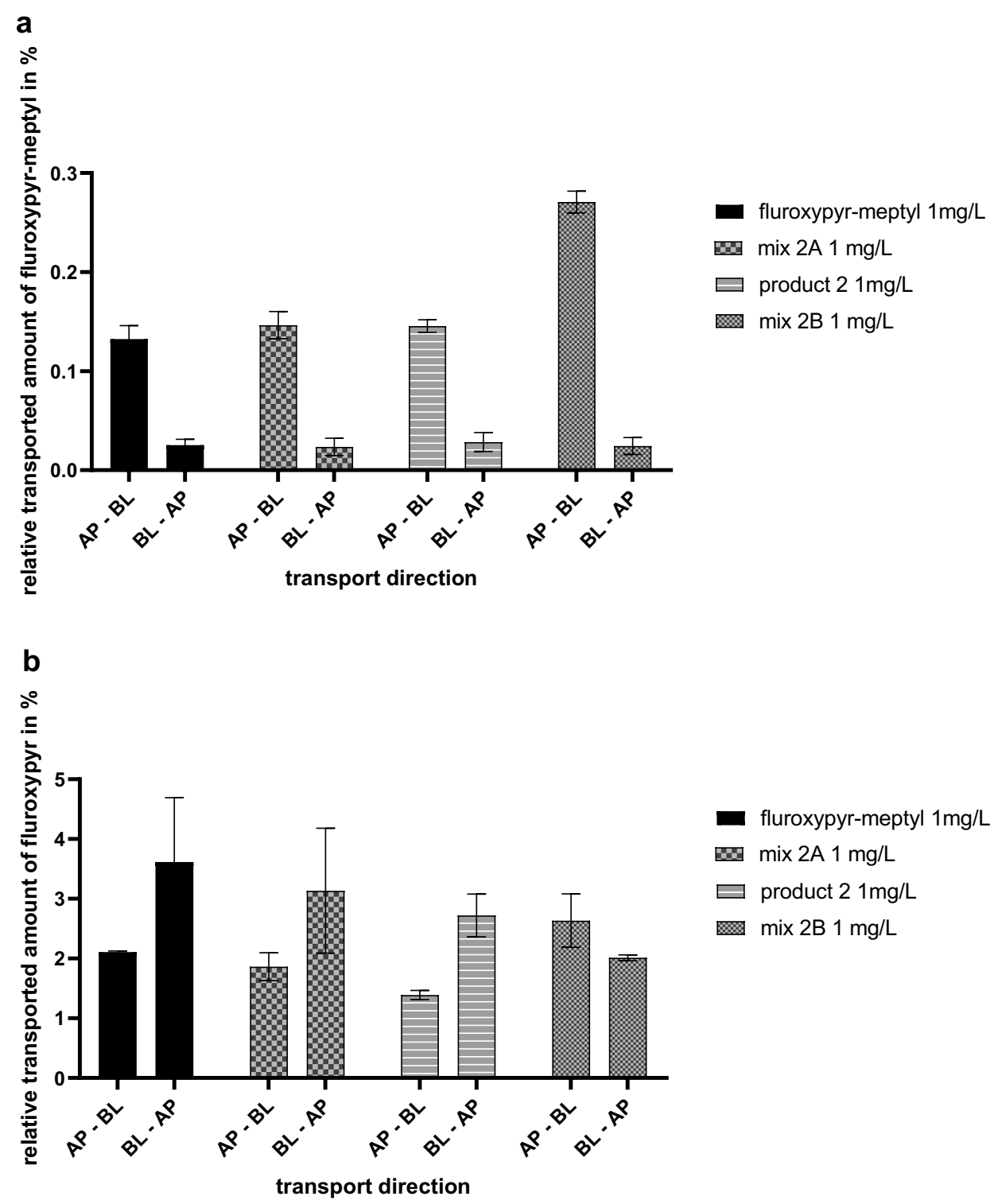

on absorption and secretion level leading to an increased bioavailability of the respective active substances and in terms of mixture toxicity also, at least partially, to deviations from the assumed concentration-addition model. Depending on the concentration of the surfactants, Pgp ATPase inhibition as well as membrane fluidisation were detected as possible mechanistic explanations for most of the surfactants.

The importance of toxicokinetic interactions was already described in several systematic review articles, e.g. by Cedergreen (2014); Martin et al. (2021). Generally, these indicate synergistic effects to be rare. However, if they occur, they usually seem rooted in toxicokinetic interactions, especially metabolic ones (Martin et al. 2021). Befittingly, a toxicokinetic interaction with CYP enzymes that leads to a more than additive mixture effect on triglyceride accumulation in human liver cells has only been described recently (Lasch et al. 2021).

In this study, both products and combinations exhibited increased cytotoxic effects at lower concentrations than the active ingredients. Since some of the investigated co-formulants exhibited cytotoxic effects individually, concentrationadditivity modelling was used to analyse potential synergistic effects due to toxicokinetic interactions.

More than additive mixture effects were found for the cytotoxicity of the combination of abamectin and the surfactants Tween ${ }^{\circledR}$ 80, Soprophor ${ }^{\circledR}$ BSU and Soprophor ${ }^{\circledR}$ 3D33, contained in product 1 . Previously, such a synergistic effect of the non-ionic surfactants Tween ${ }^{\circledR} 80$ and PEG6000 on cytotoxicity of insecticides, including abamectin was described by Li et al. (2015). However, the underlying mechanisms of interaction remained unresolved. 
Our findings support the hypothesis that the surface active co-formulants increase absorption in relation to secretion, leading to increased BL concentrations of the active substances. Since the efflux ratio for product 1 was not noticeable lower compared to the combinations with the surfactants, the impact found in the transport studies can likely be attributed to the surface active co-formulants. The higher impact on secretion emphasises the involvement of active transporters in secretory direction, such as Pgp transporters (Aungst 1999; Troutman and Thakker 2003). These findings are in line with the Pgp ATPase assay results, showing Pgp inhibition caused by Soprophor ${ }^{\circledR}$ BSU and Soprophor ${ }^{\circledR}$ 3D33.

Furthermore, all of the three surfactants increased membrane fluidity, which partially explains the more than additive effect. Tween ${ }^{\circledR} 80$ has previously been described to cause increased membrane fluidity of Caco- 2 cells below and above their respective critical micelle concentrations (Greulich 2003; Rege et al. 2002). However, this has not been described for the other two substances Soprophor ${ }^{\circledR}$ BSU and Soprophor ${ }^{\circledR}$ 3D33.

Surprisingly, mix 1A containing higher concentrations of Tween ${ }^{\circledR} 80(80 \mathrm{mg} / \mathrm{L})$, Soprophor ${ }^{\circledR}$ BSU $(40 \mathrm{mg} / \mathrm{L})$ and Soprophor ${ }^{\circledR} 3 \mathrm{D} 33(40 \mathrm{mg} / \mathrm{L})$ resulted in a lower absorbed relative amount of avermectin B1a in AP-BL transport studies. A possible explanation could be the formation of mixed micelles due to the high concentrations of the surfactants, leading to a micellar inclusion of the abamectin. This would result in a reduced freely transportable amount of abamectin. Notably, it has been described that the Pgp inhibition caused by surfactants decreases above the critical micelle concentration (Nerurkar et al. 1996).

A second more than additive mixture effect was found for the cytotoxicity of product 2 (combination of fluroxypyrmeptyl, Rhodacal ${ }^{\circledR}$ 60/BE Emulsogen ${ }^{\circledR}$ EL400 and Solgad ${ }^{\circledR}$ 150 ULN). In summary, the more than additive mixture effect shown for product 2 seems to be due to solubilisation, since the efflux ratio in the transport studies for the product and the active ingredient were nearly the same. However, depending on the concentration of the surfactants and the active ingredients further toxicokinetic interactions are possible, as shown for mix $2 \mathrm{~B}$, which contains fluroxypyrmeptyl and higher concentrations of the surfactants than in the product.

The hypothesis that further toxicokinetic interaction is possible at higher concentrations was also supported by additional results. Both surfactants increased membrane fluidity and inhibited verapamil-stimulated Pgp ATPase activity at higher concentrations. The concentrations of the surfactants in mix $2 \mathrm{~A}$ and product $2\left(0.1 \mathrm{mg} / \mathrm{L}\right.$ Rhodacal ${ }^{\circledR}$ 60/BE and $0.2 \mathrm{mg} / \mathrm{L}$ Emulsogen ${ }^{\circledR}$ EL400) are distinctly lower than the concentrations, that showed effects in the Pgp ATPase assays and in the fluorescence anisotropy measurements. Cremophor ${ }^{\circledR}$ EL (polyoxyethylene 35 castor oil CAS No. same as Emulsogen ${ }^{\circledR}$ EL400) has been described in previous studies to increase membrane fluidity in Caco-2 cells (Greulich 2003; Rege et al. 2002). Furthermore, our results for Emulsogen ${ }^{\circledR}$ EL400 are in line with previous inhibition studies of rhodamine 123 transport in Caco- 2 cells caused by Cremophor ${ }^{\circledR}$ EL, suggesting a Pgp inhibition by these surfactants (Hugger et al. 2002; Rege et al. 2002).

Furthermore, mix 2B showed a reversal of the efflux ratio of the metabolite fluroxypyr, indicating a net absorption. This is a further indication of the involvement of active transporters, which are inhibited by the surfactants at higher concentrations. An interaction with Pgp transporters is possible. Other secretory transporters expressed in Caco-2 cells, such as multidrug resistance-associated proteins 2 (MRP2) could also be responsible, as previously described: MRP2 transporters may be inhibited by several surfactants such as Cremophor ${ }^{\circledR}$ EL, Cremophor ${ }^{\circledR}$ RH40 and Solutol ${ }^{\circledR}$ HS15, PEG 2000 and pluronic block copolymers (Greulich 2003; Li et al. 2014).

Our findings as well as recent investigations imply that a more systematic consideration of toxicokinetic mixture effects is required, at least for selected examples. Nevertheless, since toxicokinetic interactions are highly related to the concentrations investigated, approaches are needed to consider concentration-dependent effects due to coformulants in PPP risk assessment.

Implemented grouping approaches for mixture selection, such as the common assessment groups (CAG) and the adverse outcome pathway (AOP), are based on toxicodynamic characteristics, whereby toxicokinetic interactions are not addressed in similar detail. This is different in respective regulations related to pharmaceuticals (ICH 1994). The development of a grouping approach based on toxicokinetic properties could hence be a way forward (Braeuning and Marx-Stoelting 2021). Concomitantly, with regard to hazard assessment based on the CLP calculation method, it should be critically assessed under which conditions the assumption of additivity is appropriate and when one would have to consider over-additivity due to toxicokinetic interactions (Hernandez et al. 2013; Kurth et al. 2019). Previous studies have hence suggested a novel tiered test strategy that considers both, toxicodynamic as well as toxicokinetic interactions (Bloch et al. 2020). Grouping approaches for toxicokinetic properties could be a useful tool for amending such an approach. Specifically, surfactants were found to modulate membrane fluidity and interact with Pgp efflux transporters, altering active substance net uptake and secretion.

Supplementary Information The online version contains supplementary material available at https://doi.org/10.1007/s00204-021-03140-x. 
Acknowledgements The authors wish to thank Dr. Corinna Kuerbis for providing the LC-MS/MS. Furthermore, we thank Max Ruediger for skillful technical support as well as helpful assistance with the analysis.

Author contributions DB and PM-S supervised the present work. DB, $\mathrm{PM}-\mathrm{S}$ and MK designed the study. MK planned and performed the experiments. B-CF supported the experiments. C-TW was consulted with respect to experimental planning and carried out the statistical analysis. MK wrote the first draft of the manuscript. DB, PM-S and TT reviewed and revised the manuscript. All authors approved the final version of the manuscript.

Funding Open Access funding enabled and organized by Projekt DEAL. This work was funded and supported by the German Federal Risk Assessment (project No. 1322-717).

Data availability Not applicable.

Code availability Not applicable.

\section{Declarations}

Conflict of interest The authors declare to have no conflict of interest.

Ethical approval Not applicable.

Consent to participate Not applicable.

Consent for publication Not applicable.

Open Access This article is licensed under a Creative Commons Attribution 4.0 International License, which permits use, sharing, adaptation, distribution and reproduction in any medium or format, as long as you give appropriate credit to the original author(s) and the source, provide a link to the Creative Commons licence, and indicate if changes were made. The images or other third party material in this article are included in the article's Creative Commons licence, unless indicated otherwise in a credit line to the material. If material is not included in the article's Creative Commons licence and your intended use is not permitted by statutory regulation or exceeds the permitted use, you will need to obtain permission directly from the copyright holder. To view a copy of this licence, visit http://creativecommons.org/licenses/by/4.0/.

\section{References}

Adler-Flindt S, Martin S (2019) Comparative cytotoxicity of plant protection products and their active ingredients. Toxicol in Vitro 54:354-366. https://doi.org/10.1016/j.tiv.2018.10.020

Anastassiades M, Scherbaum E, Tasdelen B, Stajnbaher D (2007) Recent developments in QuEChERS methodology for pesticide multiresidue analysis. Pesticide chemistry: Crop protection, public health, environmental safety $46: 439-458$

Aungst BJ (1999) P-glycoprotein, secretory transport, and other barriers to the oral delivery of anti-HIV drugs. Adv Drug Deliv Rev 39(1-3):105-116

Backhaus T, Arrhenius $\AA$, Blanck H (2004) Toxicity of a mixture of dissimilarly acting substances to natural algal communities: predictive power and limitations of independent action and concentration addition. Environ Sci Technol 38(23):6363-6370

Bloch D, Marx-Stoelting P, Martin S (2020) Towards a tiered test strategy for plant protection products to address mixture toxicity by alternative approaches in human health assessment. Pest Manag Sci 76(10):3326-3332. https://doi.org/10.1002/ps.6034

Braeuning A, Marx-Stoelting P (2021) Mixture prioritization and testing: the importance of toxicokinetics. Arch Toxicol. https://doi. org/10.1007/s00204-021-03026-y

Cedergreen N (2014) Quantifying synergy: a systematic review of mixture toxicity studies within environmental toxicology. PLoS ONE 9(5):e96580

De Rosario-Martinez H, Fox J, Team RC, De Rosario-Martinez MH (2015) Package 'phia.' CRAN Repos Retriev 1:2015

Dudeja PK, Anderson KM, Harris JS, Buckingham L, Coon JS (1995) Reversal of multidrug resistance phenotype by surfactants: relationship to membrane lipid fluidity. Arch Biochem Biophys 319(1):309-315. https://doi.org/10.1006/abbi.1995.1298

EC (2008) 1272/2008,'Regulation (EC) No 1272/2008 of the European Parliament and of the Council of 16 December 2008 on classification, labelling and packaging of substances and mixtures, amending and repealing Directives 67/548/EEC and 1999/45/EC, and amending Regulation (EC) No 1907/2006. Off J Eur Union 50:353

EC (2009) No 1107/2009 of the European Parliament and of the Council of 21 October 2009 concerning the placing of plant protection products on the market and repealing Council Directives 79/117/EEC and 91/414/EEC EU, Brussels. Off J Eur Union 91:1-50

EC (2013a) Commission Regulation (EU) No 283/2013 of 1 March 2013 setting out the data requirements for active substances, in accordance with Regulation (EC) No 1107/2009 of the European Parliament and of the Council concerning the placing of plant protection products on the market. Off J Eur Union 3:1-84

EC (2013b) Commission Regulation (EU) No 284/2013 of 1 March 2013 setting out the data requirements for plant protection products, in accordance with Regulation (EC) No 1107/2009 of the European Parliament and of the Council concerning the placing of plant protection products on the market. Off J Eur Union 93:85-152

Greulich M (2003) Einfluss von Tensiden auf die Resorption von Substraten der ABC-Transportproteine. Dissertation, Ruprecht Karl University of Heidelberg

Hazen JL (2000) Adjuvants-terminology, classification, and chemistry1. Weed Technol 14(4):773-784. https://doi.org/10.1614/ 0890-037x(2000)014[0773:Atcac]2.0.Co;2

Hernandez AF, Parron T, Tsatsakis AM, Requena M, Alarcon R, Lopez-Guarnido O (2013) Toxic effects of pesticide mixtures at a molecular level: their relevance to human health. Toxicology 307:136-145. https://doi.org/10.1016/j.tox.2012.06.009

Hothorn T, Bretz F, Westfall P (2008) Simultaneous inference in general parametric models. Biometrical J J Math Methods Biosci 50(3):346-363

Hugger ED, Audus KL, Borchardt RT (2002) Effects of poly(ethylene glycol) on efflux transporter activity in Caco-2 cell monolayers. J Pharm Sci 91(9):1980-1990. https://doi.org/10.1002/jps. 10175

ICH (1994) Note for guidance on toxicokinetics: the assessment of systemic exposure in toxicity studies S3A ICH Harmonisation for better health. Switzerland, Geneva

Junghans M, Backhaus T, Faust M, Scholze M, Grimme LH (2006) Application and validation of approaches for the predictive hazard assessment of realistic pesticide mixtures. Aquat Toxicol 76(2):93-110. https://doi.org/10.1016/j.aquatox.2005.10.001

Kienhuis AS, Slob W, Gremmer ER, Vermeulen JP, Ezendam J (2015) A dose-response modeling approach shows that effects from mixture exposure to the skin sensitizers isoeugenol and cinnamal are in line with dose addition and not with synergism. Toxicol Sci 147(1):68-74. https://doi.org/10.1093/toxsci/kfv109

Kienzler A, Berggren E, Bessems J, Bopp S, van der Linden S, Worth A (2014) Assessment of mixtures-review of regulatory requirements 
and guidance. European Commission, Joint Research Centre, Science and Policy Reports Luxembourg

Kurth D, Wend K, Adler-Flindt S, Martin S (2019) A comparative assessment of the CLP calculation method and in vivo testing for the classification of plant protection products. Regul Toxicol Pharmacol 101:79-90. https://doi.org/10.1016/j.yrtph.2018.11.012

Lasch A, Lichtenstein D, Marx-Stoelting P, Braeuning A, Alarcan J (2020) Mixture effects of chemicals: the difficulty to choose appropriate mathematical models for appropriate conclusions. Environ Pollut 260:113953. https://doi.org/10.1016/j.envpol. 2020.113953

Lasch A, Marx-Stoelting P, Braeuning A, Lichtenstein D (2021) More than additive effects on liver triglyceride accumulation by combinations of steatotic and non-steatotic pesticides in HepaRG cells. Arch Toxicol 95(4):1397-1411

Lespine A, Martin S, Dupuy J et al (2007) Interaction of macrocyclic lactones with P-glycoprotein: structure-affinity relationship. Eur J Pharm Sci 30(1):84-94. https://doi.org/10.1016/j.ejps.2006.10. 004

Li L, Yi T, Lam CW-K (2014) Inhibition of human efflux transporter ABCC2 (MRP2) by self-emulsifying drug delivery system: Influences of concentration and combination of excipients. J Pharm Pharm Sci 17(4):447-460

Li D, Wu X, Yu X, Huang Q, Tao L (2015) Synergistic effect of nonionic surfactants Tween 80 and PEG6000 on cytotoxicity of insecticides. Environ Toxicol Pharmacol 39(2):677-682. https://doi. org/10.1016/j.etap.2014.12.015

Li-Blatter X, Nervi P, Seelig A (2009) Detergents as intrinsic P-glycoprotein substrates and inhibitors. Biochim Biophys Acta 1788(10):2335-2344. https://doi.org/10.1016/j.bbamem.2009. 07.010

Lichtenstein D, Ebmeyer J, Knappe P et al (2015) Impact of food components during in vitro digestion of silver nanoparticles on cellular uptake and cytotoxicity in intestinal cells. Biol Chem 396(11):1255-1264

Martin O, Scholze M, Ermler S et al (2021) Ten years of research on synergisms and antagonisms in chemical mixtures: a systematic review and quantitative reappraisal of mixture studies. Environ Int 146:106206

Nerurkar MM, Burton PS, Borchardt RT (1996) The use of surfactants to enhance the permeability of peptides through Caco- 2 cells by inhibition of an apically polarized efflux system. Pharm Res 13(4):528-534

Pinheiro JC, Bates DM (2000) Linear mixed-effects models: basic concepts and examples. Mixed-effects models in S and S-Plus. Springer, New York, pp 3-56

Pinheiro J, Bates D, DebRoy S, Sarkar D (2020) R Core Team. 2020. nlme: linear and nonlinear mixed effects models. R package version 3. 1-148. https://cran.r-project.org/web/packages/nlme/ index.html

R Core Team (2020) R: A language for statistical computing. R Foundation for Statistical Computing. Vienna, Austria. https://www.Rproject.org

Rege BD, Lawrence XY, Hussain AS, Polli JE (2001) Effect of common excipients on Caco-2 transport of low-permeability drugs. J Pharm Sci 90(11):1776-1786

Rege BD, Kao JP, Polli JE (2002) Effects of nonionic surfactants on membrane transporters in Caco- 2 cell monolayers. Eur J Pharm Sci 16(4-5):237-246

Repetto G, del Peso A, Zurita JL (2008) Neutral red uptake assay for the estimation of cell viability/cytotoxicity. Nat Protoc 3(7):11251131. https://doi.org/10.1038/nprot.2008.75

Stock V, Bohmert L, Lisicki E et al (2019) Uptake and effects of orally ingested polystyrene microplastic particles in vitro and in vivo. Arch Toxicol 93(7):1817-1833. https://doi.org/10.1007/ s00204-019-02478-7

Troutman MD, Thakker DR (2003) Rhodamine 123 requires carriermediated influx for its activity as a P-glycoprotein substrate in Caco-2 cells. Pharm Res 20(8):1192-1199

Van Cott A, Hastings CE, Landsiedel R, Kolle S, Stinchcombe S (2018) GHS additivity formula: can it predict the acute systemic toxicity of agrochemical formulations that contain acutely toxic ingredients? Regul Toxicol Pharmacol 92:407-419. https://doi.org/10. 1016/j.yrtph.2017.12.024

Weinheimer M, Fricker G, Burhenne J, Mylius P, Schubert R (2017) The application of P-gp inhibiting phospholipids as novel oral bioavailability enhancers - an in vitro and in vivo comparison. Eur J Pharm Sci 108:13-22. https://doi.org/10.1016/j.ejps.2016.08.055

Woodcock D, Linsenmeyer M, Chojnowski G et al (1992) Reversal of multidrug resistance by surfactants. Br J Cancer 66(1):62-68

Zahn E, Wolfrum J, Knebel C et al (2018) Mixture effects of two plant protection products in liver cell lines. Food Chem Toxicol 112:299-309. https://doi.org/10.1016/j.fct.2017.12.067

Zeng N, Gao X, Hu Q et al (2012) Lipid-based liquid crystalline nanoparticles as oral drug delivery vehicles for poorly water-soluble drugs: cellular interaction and in vivo absorption. Int J Nanomedicine 7:3703-3718. https://doi.org/10.2147/ijn.S32599

Publisher's Note Springer Nature remains neutral with regard to jurisdictional claims in published maps and institutional affiliations. 